\title{
Low CyaA expression and anti-cooperative binding of CAMP to CRP frames the scope of the cognate regulon of Pseudomonas putida
}

Arce-Rodríguez, Alejandro; Nikel, Pablo I.; Calles, Belén; Chavarría, Max; Platero, Raúl; Krell, Tino; de Lorenzo, Victor

\section{Published in:}

Environmental Microbiology

Link to article, DOI:

$10.1111 / 1462-2920.15422$

Publication date:

2021

Document Version

Peer reviewed version

Link back to DTU Orbit

Citation (APA):

Arce-Rodríguez, A., Nikel, P. I., Calles, B., Chavarría, M., Platero, R., Krell, T., \& de Lorenzo, V. (2021). Low CyaA expression and anti-cooperative binding of CAMP to CRP frames the scope of the cognate regulon of Pseudomonas putida. Environmental Microbiology, 23(3), 1732-1749. https://doi.org/10.1111/1462-2920.15422

\section{General rights}

Copyright and moral rights for the publications made accessible in the public portal are retained by the authors and/or other copyright owners and it is a condition of accessing publications that users recognise and abide by the legal requirements associated with these rights.

- Users may download and print one copy of any publication from the public portal for the purpose of private study or research.

- You may not further distribute the material or use it for any profit-making activity or commercial gain

- You may freely distribute the URL identifying the publication in the public portal 
Anti-cooperative binding of CAMP to the CRP regulator of Pseudomonas putida endows the regulon with a distinct in vivo functionality

by

$$
\begin{gathered}
\text { Alejandro Arce-Rodríguez }{ }^{1} \text {, Pablo I. Nikel2 }{ }^{2} \text { Belén Calles }{ }^{3} \text {, Max Chavarría4 }{ }^{4} \text { Raúl Platero }{ }^{5} \text {, } \\
\text { Tino Krell }{ }^{6} \text { and Victor de Lorenzo }{ }^{{ }^{*}}
\end{gathered}
$$

${ }^{1}$ Department of Molecular Bacteriology, Helmholtz Centre for Infection Research, Braunschweig 38124, Germany. ${ }^{2}$ The Novo Nordisk Foundation Center for Biosustainability, Technical University of Denmark, 2800 Kongens Lyngby, Denmark. 35ystems Biology Department, Centro Nacional de BiotecnologíaCSIC, Campus de Cantoblanco, Madrid 28049, Spain. ${ }^{4}$ Escuela de Química, Universidad de Costa Rica, San José 2060, Costa Rica. ${ }^{5}$ Departamento de Bioquímica y Genómica Microbianas, Instituto de Investigaciones Biológicas Clemente Estable, MEC, Montevideo, Uruguay. ${ }^{6}$ Department of Environmental Protection, Estación Experimental del Zaidín CSIC, Granada 18008, Spain

Originality-Significance Statement. One of the general rules of comparative genomics is that DNA sequence similarity between two given genes implies functional similarity as well. The CAMP-CRP system was one of the first regulatory devices studied in $E$. coli and its key role as a central regulatory device of metabolic transactions in this bacterium has been broadly demonstrated. It is thus tempting to assign the same function to the corresponding genes when found in other bacterial species. Surprisingly, the genome of the soil bacterium Pseudomonas putida encodes the same regulatory parts of the cAMP/CRP system of $E$. coli but its physiological role is altogether alien to metabolic control. In this article we provide a mechanistic basis for such a functional shift, that ultimately stems from the affinities that rule CAMP-CRP binding in $P$. putida. On this basis, we argue that the specific role of a given genetic device depends not only of the intrinsic properties of its components and their connections, but most importantly, of the parameters that control dynamic interplay among them.

* Correspondence to: Víctor de Lorenzo, Centro Nacional de Biotecnología (CNB-CSIC) Campus de Cantoblanco, Madrid 28049, Spain. Tel.: 34-91 58545 36. Fax: 34-91 58545 06. E-mail: vdlorenzo@cnb.csic.es 
SUMMARY

2

3 Although the soil bacterium Pseudomonas putida KT2440 bears a bona fide adenylate cyclase gene

4 (cyaA) intracellular concentrations of cAMP are barely detectable. By using a battery of reporter systems 5 and direct quantification of cAMP under various conditions, we show that such low levels of the molecule 6 stem from the stringent regulation of its synthesis, efflux and degradation. Poor production of cAMP

7 resulted both from the low catalytic activity of CyaA and inefficient translation of its mRNA. Moreover, 8 inactivation of the cAMP-phosphodiesterase pde gene led to intracellular accumulation of the cyclic 9 nucleotide, exposing an additional source of cAMP drain in vivo. But even with such low levels of cAMP,

10 P. putida sustained a perfectly active cAMP signaling pathway that propagates into a large regulon.

11 Genetic and biochemical evidence indicated that such phenomenon ultimately resulted from the unusual 12 binding parameters of CAMP to CRP. This included an ultratight CAMP-CrpP. putida affinity $\left(K_{D}\right.$ of $45.0 \pm$ $13 \quad 3.4 \mathrm{nM}$ ) and an atypical 1:1 effector/dimer stoichiometry that obeyed to an infrequent anti-cooperative 14 binding mechanism. It thus seems that keeping the same regulatory parts and their relational logic but 15 changing the interaction parameters enables genetic devices to take over entirely different domains of 16 the functional landscape.

18 Keywords: Pseudomonas putida, cAMP, Crp, Adenylate Cyclase, cAMP-phosphodiesterase, 19 metabolism, negative cooperativity

22 Since discovery of cAMP, this metabolite has been recognized as a universal second messenger due 23 to the myriad of regulatory roles that it plays in virtually all kingdoms of life (Gancedo, 2013). This is in 24 part due to its rapid turnover, which is tightly controlled by its rate of synthesis from ATP by the enzyme 25 adenylate cyclase (AC) and/or its efflux and hydrolysis by specific cAMP-phosphodiesterases (PDEs) 26 (McDonough and Rodriguez, 2011). In bacteria, CAMP was originally described in E. coli and shortly 27 after it was linked to the control of carbon catabolite repression or CCR (i.e. the mechanism by which 28 bacteria employ preferentially one carbon source in respect to others; Makman and Sutherland, 1965; 29 Ullmann and Monod, 1968). Currently, it is accepted that CCR in enterobacteria is controlled by the rate 30 of cAMP synthesis catalyzed by the AC. In the presence of a preferred carbon source (such as glucose), 31 the carbohydrate is phosphorylated and transported inside the cell by the EllA enzyme of the 
1 phosphoenolpyruvate-carbohydrate phosphotransferase system (PTS), in order to be consumed by the

2 glycolytic pathway. When glucose is exhausted, the phosphorylated ElIA enzyme accumulates in the 3 cytoplasm and stimulate the enzymatic activity of the AC (Deutscher, 2008). The changes in intracellular

4 cAMP levels are then perceived by the cAMP-receptor protein (Crp) trough allosteric interaction with its $5 \quad \mathrm{~N}$-terminal cNMP binding domain. The interaction with cAMP triggers a series of conformational changes 6 in this transcriptional factor that enable its C-terminal DNA recognition domain to activate the 7 transcription of hundreds of genes (many of them directly involved in the utilization of non-preferred carbon compounds) (Shimada et al., 2011; Seok et al., 2014).

10 Owing that much of the initial research on cAMP was done in E. coli, it was typically assumed that the role of this molecule is always related to the control of differential carbon source consumption in bacteria.

12 However, this paradigmatic vision has changed during the last years due to many studies that expanded 13 the functions regulated by cAMP-Crp, relegating the control of CCR almost exclusively to enterobacteria. 14 These traits include the control of basic metabolic adaptations such as biofilm formation (Hufnagel et al., 15 2016), motility (Fahrner and Berg, 2015), survival to oxidative stress (Molina-Quiroz et al., 2018) or the 16 CRISPR/Cas antiviral defense mechanism (Yang et al., 2020). Moreover, in important pathogenic 17 bacteria such as Klebsiella pneumoniae, Vibrio cholerae or $P$. aeruginosa, the Crp-cAMP homologue 18 systems regulate the transition between virulent and avirulent behaviors (McDonough and Rodriguez, 192011 ; Xue et al., 2016). This diversification of functions for the same regulatory system in many bacteria 20 exhibit an evolutionary mechanism through which regulons governed by the same transcription factor 21 can dramatically diversify in different hosts, in a clear example of regulatory exaptation at molecular 22 level (Milanesio et al., 2011).

24 Pseudomonas putida is a ubiquitous bacterium that could be found colonizing soil, rhizosphere and 25 water environments. Over the last years, this bacterium has been renowned as a robust chassis for 26 industrial biocatalysis processes, due to its remarkable versatile metabolism, its high tolerance to toxic 27 compounds, and the wealth of genetic tools available for genomic engineering (Nikel and de Lorenzo, 28 2018). Much of the biotechnological interest on P. putida stems from the distinct architecture of its central 29 carbon metabolism when compared to other microbes. These differences allow the bacterium to produce 30 a high concentration of $\mathrm{NAD}(\mathrm{P}) \mathrm{H}$ to cope with redox-intensive reactions (Nikel et al., 2015; Akkaya et 31 al., 2018). Along with the differences in central metabolism, the preferential utilization of carbon 
1 compounds in P. putida also differs significantly compared to other microorganisms. Interestingly, 2 neither variations in the intracellular cAMP (Phillips and Mulfinger, 1981; Rojo, 2010), nor the mutation 3 of crp or cyaA genes altered significantly the gross metabolic profiles in this bacterium (Milanesio et al., 4 2011). These observations rule out the possibility that either cAMP or Crp p. putida plays a role in the control 5 of CCR. Conversely, the preferential selection of carbon sources in P. putida seems to be governed by 6 a sophisticated posttranscriptional mechanism that involves the interaction of sRNA antagonists, the 7 catabolite repression control protein $\mathrm{Crc}$ and the RNA binding protein Hfq (Moreno et al., 2015). 8 Moreover, some CCR-unrelated functions orchestrated by cAMP-Crp in P. putida have been recently 9 reported. These features include the utilization of various amino acids (such as phenylalanine) or 10 dipeptides as nitrogen sources, or the resistance to a small number of bactericidal agents (Milanesio et 11 al., 2011; Herrera et al., 2012). More recently, (Xiao et al., 2020) showed that Crp P. putida directly 12 represses the expression of gcsA (a novel diguanylate cyclase involved in the repression of swimming 13 motility) in a cAMP dependent manner.

In addition to its regulatory duties, another puzzling aspect of CAMP-Crp P. putida $_{\text {is }}$ the mechanistic of Crp 16 activity. As it has been shown, P. putida maintains its cAMP concentrations remarkably low regardless 17 of its growth conditions (Arce-Rodriguez et al., 2012). Nevertheless, Crpp. putida activation by cAMP is 18 ultimately required to trigger the transcription of its cognate promoters (Milanesio et al., 2011). Hence, 19 how is possible to hold an active cAMP-Crp system with such limited effector concentrations and which 20 mechanisms are used by $P$. putida to keep the cAMP at bay? In this work we have explored these issues 21 and we have found that $P$. putida has adapted its entire cAMP-Crp regulatory system to function with 22 extremely short amounts of the effector. This low intracellular cAMP pool is maintained by controlling 23 every step of cAMP-production, from the expression of its unique AC to the degradation and excretion 24 of the metabolite outside the cell. By the titration of cyclic nucleotides to the apo-Crpp. putida, we finally 25 show that this transcriptional factor is able to detect such extremely low amounts of cAMP due to its extremely high affinity for the metabolite and its unique 1:1 effector/dimer stoichiometry.

RESULTS 
1 As we have previously described, the genome of $P$. putida KT2440 encodes singular orthologues of one

2 class I adenylate cyclase (cyaA) and the cAMP receptor protein (crp) (Milanesio et al., 2011).

3 Additionally, a protein encoding a class III cAMP-phosphodiesterase (CpdA) was characterized in its

4 closely relative $P$. aeruginosa as being responsible for the degradation of cAMP (Fuchs et al., 2010).

5 We therefore sought out for a homolog of this protein in the genome of $P$. putida using BLASTP. Only

6 one protein of 266 aa residues resulted to be highly similar to CpdAP. aeruginosa, with $54 \%$ identity and

$769 \%$ similarity. This positive match is encoded by the gene locus PP_4917, which was previously

8 annotated as Icc protein (Nelson et al., 2002). However, after the last update of P. putida KT2440

9 genome (Belda et al., 2016) the gene was renamed as pde, which stands for 3',5'-cyclic-nucleotide

10 phosphodiesterase. The genomic location and expression profile of PP_4917 is shown in Fig. 1A. To

11 get further insights into the function of PP_4917 product, its amino acid sequence was aligned with the

12 sequence of five previously described cAMP-phosphodiesterases from bacteria. The alignment showed

13 that $P$. putida PP_4917 preserves all the 13 residues that are absolutely conserved among class III

14 phosphodiesterases (Supplementary Fig. S1). Unlike crp and cyaA, that are transcribed as stand-alone

15 genes (Fig. 1B and 1C), the pde genomic context could enable this gene to be co-transcribed as part of

16 a large polycistronic mRNA along with other important genes like par $C$ and parE, encoding the $A$ and $B$

17 subunits of a type IV DNA topoisomerase, respectively (Fig. 1A). However, the levels of transcription of

18 pde were found to be considerably lower than those of the rest of its surrounding genes, regardless of

19 the carbon source used for bacterial growth (Fig. 1A). This result suggests that $P$. putida pde could also

20 be expressed independently of its genomic context in a similar fashion as crp and cyaA (Fig. 1B, 1C).

21 Next, in order to verify the activity of Pde as a genuine 3',5'-cyclic-AMP phosphodiesterase, we

22 investigated whether the loss of $p d e$ affected the intracellular accumulation of cAMP.

24 Inactivation of pde gene increases the transcriptional activation of cAMP-Crp dependent promoters

26 A reporter system was designed to correlate the intracellular levels of cAMP with the fluorescence

27 produced by the GFP protein expressed through a Pcc-41.5 synthetic promoter (Gaston et al., 1990). This

28 correlation is achieved since transcription from Pcc-41.5 is dependent on the activation by the cAMP-Crp

29 complex through a class II Crp-activation mechanism (Busby and Ebright, 1999). The reporter system

30 (which is carried in plasmid pCAMPS, Table 1) was transformed into wild-type P. putida KT2440 and

31 into its crp, cyaA and pde mutants. As stated above, cAMP production (and therefore Crp activity) in $E$. 
1 coli is tightly linked to carbon consumption via the CCR mechanism (Deutscher, 2008). Although the

2 Crp-cAMP system of $P$. putida seems to be independent of carbon source consumption (Milanesio et 3 al., 2011), we sought out whether different metabolic regimes could affect the activation of the cAMP

4 sensor. Thus, the strains bearing pCAMPS plasmid were grown in M9 minimal medium with either 5 glycolytic or gluconeogenic carbon sources and the GFP fluorescence produced was recorded along 6 the growth curve. Fig. 2 shows the relative GFP fluorescence measured in exponential and stationary 7 phase of growth. Noteworthy, the fluorescence levels in the wild-type strain KT2440 were very similar 8 regardless of the carbon source used for growth. This result reaffirms our previous findings that the Crp9 cAMP system is not linked with carbon consumption in P. putida (Milanesio et al., 2011). We also noticed 10 that in both $\Delta c y a A$ and $\Delta c r p$ mutants the intensity of GFP was significantly lower than in the wild-type 11 strain in all the carbon sources tested, which reflects the activation of the synthetic promoter by the 12 cAMP-Crp complex. Fig. 2 also shows the GFP fluorescence in the pde transposon mutant. We 13 expected that, if Pde is an authentic cAMP-phosphodiesterase, the intracellular pool of this metabolite 14 in the mutant should increase. With higher cAMP levels, the amount of cAMP-activated Crp would also 15 raise and therefore it will produce an increment in the transcription of cAMP-Crp activated promoters 16 such as Pcc-41.5. This was indeed the case when cells were grown in sugars (glucose and fructose) as 17 carbon and energy sources. No significant difference was observed when cells were grown in succinate, 18 suggesting that Pde activity might be itself subject to metabolic control.

P. putida retain very low cAMP levels

22 To correlate the genetic data above with the actual cAMP available in vivo to the cognate regulatory 23 device we developed a sensitive HPLC-ESI-MS analytical procedure to test and quantify the levels of 24 this cyclic nucleotide both in the culture supernatant and the cytoplasm of bacteria grown in different 25 media (see Experimental procedures). Note that the quenching method was adapted for full recovery of 26 the analyte at the moment of cell harvest. As control of sensitivity for this method, equivalent samples 27 of wild-type and cyaA strains of $E$. coli were also processed. It is noteworthy that $E$. coli wild type was 28 cultured in conditions where it is expected to produce high amounts of cAMP (Joseph et al., 1982). 29 Conversely, the $\Delta c y a A$ strain of $E$. coli was cultured in $0.2 \%(\mathrm{w} / \mathrm{v})$ glucose since it fails to grow on 30 succinate as carbon source. The results of these experiments are shown in Fig. 3A. As anticipated, cAMP was found both intracellularly $(\sim 2.5 \mu \mathrm{M})$ and in the external medium $(\sim 16 \mu \mathrm{M})$ of cultures of the 
1 wild-type E. coli strain. In contrast, cAMP was not detected in the cyaA strain, a result that was expected

2 for a mutant in the sole adenylate cyclase of this bacterium. The same procedure was then applied to

3 P. putida KT2440 and its cyaA and pde mutants while growing on succinate or glucose. In contrast to

4 E. coli, we were unable to detect the metabolite in P. putida cells collected and processed with the same

5 protocol (Fig. 3B and 3C, left panels). While earlier genetic data suggested cAMP levels in $P$. putida to

6 be very low (Phillips and Mulfinger, 1981; Milanesio et al., 2011; Arce-Rodriguez et al., 2012), we

7 wondered how the cyaA gene (and thus production of CAMP) was required to activate the $P_{C C-41.5}-G F P$

8 fusion borne by pCAMPS (Fig. 2) without any detectable production of CAMP, at least with the level of

9 sensitivity of our analytical method. One possibility is that cAMP is indeed produced but the levels are

10 so low that they scape the HPLC-ESI-MS technology adopted. This may stem from a very low activity

11 of CyaA or a very high activity of Pde-or both. To shed some light on this matter, we turned our attention

12 to the determinants of $c y a A$ expression as a way to artificially increase cAMP production

13

14 The cyaA gene of P. putida is transcribed, but not efficiently translated in P. putida

16 Quantification of CAMP (Fig. 3B and 3C, left panels) confirmed that $P$. putida cells produce undetectable 17 levels of the cyclic nucleotide, even when the Pde phosphodiesterase gene was disrupted. This low 18 cAMP production could be caused inter alia by a deficient enzymatic activity of the adenylate cyclase 19 itself, but also due to low transcription/translation rates of the cyaA. Genome-wide transcriptomic 20 analysis of $P$. putida performed by our group and by others (Yuste et al., 2006) have shown that the 21 adenylate cyclase specific mRNA is efficiently transcribed regardless of the growth conditions (Fig. 1C).

22 On the other hand, close examination of $P$. putida 5' UTR of cyaA mRNA revealed that the putative 23 Shine-Dalgarno (SD) motif of this gene is suboptimal according to the GGAGG nucleotide core that 24 interacts directly with the anti-SD sequence of the 16S rRNA ((Ma et al., 2002); Supplementary Fig. S2).

25 The absence of a good quality SD could inhibit proper formation of the translation initiation complex, 26 preventing the efficient translation of cyaA mRNA into the adenylate cyclase enzyme. To test this 27 hypothesis, two plasmid-borne translational (pARPcyaA1) and transcriptional (pARPcyaA2) fusions of 28 the cyaAp. putida promoter $\left(\mathrm{P}_{\text {cyaA }}\right)$ were constructed in frame with the lacZ gene (Table 1). The initial 29 quantification of cyaA'-'lacZ translational fusion activity was performed by the classical $\beta$-galactosidase 30 assay described by Miller (Miller, 1972). Nonetheless, the values obtained were too low to be significant 31 for this method (i.e. <15 Miller Units, results not shown). Therefore, we resorted to the ultra-sensitive 
1 Galacto-Light Plus ${ }^{\mathrm{TM}}$ commercial system. Fig. 4A shows the corresponding LacZ activity for both

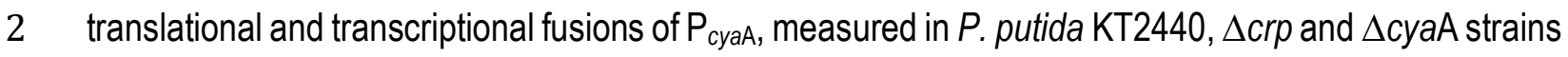
3 grown on different carbon sources (succinate, glucose, fructose). The results reveal a remarkable

4 difference amongst the transcription and the translation levels of the $c y a A_{P}$. putida gene, the transcriptional 5 activity of the promoter being between 10-30 fold-change higher than the translational activity in the 6 conditions tested. As observed, neither deletion of crp nor cyaA genes affect the activity of the $\mathrm{P}_{\text {cyaA, }}$

7 conversely to $E$. coli where the CAMP-Crp complex repress $c y a A_{E \text {.coli }}$ expression trough binding to the 8 P2 promoter of the gene (Aiba, 1985; Mori and Aiba, 1985). This result was confirmed by an 9 electrophoretic mobility shift assay (EMSA) of a $\sim 200$ bp end-labeled DNA fragment comprising the 10 upstream region of $c y a A$ p. putida gene and purified Crpp. putida. Even at protein concentrations as high as $115 \mu \mathrm{M}, \mathrm{Crp}_{P \text {. putida }}$ was not able to retard noticeably the electrophoretic migration of the $\mathrm{P}_{\text {cyaA }}$ DNA probe 12 despite of the presence of CAMP (not shown).

13

14 Besides the translation initiation bottleneck of CyaA just described, we noticed also that the codon usage 15 through the gene was clearly suboptimal, what could surely add to a poor expression of the signal. To 16 overcome this state of affairs we reconstructed a fully synthetic version of CyaAp. putida that maintained 17 the primary amino amino acid sequence but with translation signals, codon usage and other features 18 optimized for a better expression of the enzyme (see Experimental procedures and Supplementary Fig. 19 S3).

21 Pde phosphodiesterase contributes to the low levels of cAMP in P. putida

23 To validate the enhanced cyaA version described above (Supplementary Fig. S3; named hereafter as 24 cyaA-GA), its activity was first tested in E. coli. To this end, its coding sequence was cloned under the 25 control of lacla-P trc of pVTR-A (Table 1), and the Notl fragment from this vector passed to the broad host 26 range plasmid pSJ33 (Table 1), thereby generating pARC5. This plasmid, along with control constructs 27 pARC2 (encoding cyaA of $E$. coli) and pMZC5 (expressing native cyaA from P. putida) were transferred into the E. coli mutants W3110 cyaA and the cAMP-hypersensitive TP610A strain (Crasnier and Danchin, 29 1990). Transformed cells were plated onto MacConkey agar to observe the complementation of the 30 maltose utilization phenotype. As shown in Fig. 5, only the optimized cyaA-GA gene was able to partially restore the consumption of maltose (red colonies) when it was transformed into E. coli W3110 cyaA and 
1 cultured in presence of IPTG (Fig. 5 panel 3). On the other hand, native cyaAp. putida failed to restore this

2 phenotype regardless of the presence of the inducer (Fig. 5 panel 2). This observation was even more

3 evident when both plasmids were transferred to the cAMP-hypersensitive strain TP610A. In this case,

4 the native cyaA from P. putida was able to complement the maltose utilization phenotype in the $E$. coli

5 host, but exclusively when it was overproduced by the addition of IPTG (Fig. 5, panel 5). Conversely,

6 overexpression of cyaA-GA was not necessary to complement the maltose phenotype (Fig. 5, panel 6).

7 Moreover, overproduction of cyaA-GA by IPTG resulted to be toxic for strain TP610A.

9 Once the cyclase activity of the refactored cyaA-GA gene product was verified, the cognate DNA 10 sequence was cloned anew into pSEVA424 (Table 1), transformed into $P$. putida strains $\Delta c y a A$ and $11 p d e^{-}$, and its cAMP levels measured both intracellularly and in the extracellular medium with the same 12 protocol described above. In this case, a clear boost of cAMP production was observed in cultures of $P$. 13 putida bearing the pARC5 plasmid (Fig. 3B and C, right panel). Similarly as in E. coli, cyclic-AMP was 14 mainly present in the culture supernatants of $P$. putida, reflecting a process in which CAMP is efficiently 15 transported outside the cell. Importantly, we observed that cAMP concentrations were significantly 16 higher in the pde ${ }^{-}$mutant compared to wild type $P$. putida KT2440, in both succinate and glucose. The 17 results of Fig. 3B and 3C (right panels), together with the homology studies of pde (Supplementary Fig. 18 S1) and the observation that GFP fluorescence produced by $P_{C C-41.5}$ increase in the pde- strain (Fig. 2), 19 confirm that [i] the CyaA protein is a perfectly functional cAMP cyclase, [ii] the low levels of the cyclic 20 nucleotide in P. putida can be traced to a very poor translation of the cyaA mRNA and [iii] Pde is a 21 functional and genuine cAMP-phosphodiesterase that further helps to keep cAMP levels low.

23 Influence of extracellular CAMP in the activation of PCC-41.5-GFP synthetic reporter

25 Due to the previous observation that cAMP was accumulated in the extracellular cultures of both $P$. 26 putida and E. coli (compared to the intracellular milieu), the next step was to analyze whether the cyclic 27 nucleotide could be transported back to the cytoplasmic space. First, the ability of an E. coli cyaA deficient strain to grow in maltose as sole carbon sink was assessed upon addition extracellular cAMP. 29 In normal conditions, a cyaA-deficient $E$. coli is unable to metabolize this carbon source due to the lack 30 of Crp activation. However, the amendment of high concentrations (i.e. $100 \mu \mathrm{M}-1 \mathrm{mM}$ ) of cAMP to the culture medium restored the growth in maltose, indicating that $E$. coli is able to uptake and use external 
1 cAMP (Fig. 6A). Next, we examined the cAMP-Crp dependent activation of the Pcc-41.5 synthetic 2 promoter by exogenous CAMP. In order to do so, E. coli W3110 cyaA strain was transformed with plasmid pCAMPS and production of GFP fluorescence was monitored in the absence and in the

4 presence of different cAMP concentrations. As shown in Fig. 6B (left panel), GFP signal strongly increased upon addition of cAMP. Furthermore, the fluorescence increase was proportional to the amount of cAMP added, confirming that $E$. coli efficiently sense the effector present in the extracellular 7 milieu.

9 Following this, the reporter plasmid pCAMPS was transformed into P. putida KT2440 strain and its $10 \Delta c y a A$ derivative in order to analyze its behavior. Cells were grown in equivalent conditions as those used in the previous experiments with $E$. coli to record the GFP fluorescence as an indicator of cAMP 12 uptake. In a similar fashion as observed in the experiments with $E$. coli, the GFP intensity was 13 significantly lower in the cyaA deficient strain of $P$. putida compared to its wild-type counterpart (see Fig. $146 \mathrm{~B}$, right panel). However, in this case addition of cAMP did not affect GFP fluorescence even at concentrations as high as $1 \mathrm{mM}$, suggesting that-contrary to $E$. coli bacterium- $P$. putida is neither permeable to cAMP, nor able to actively internalize extracellular cAMP at least in the conditions tested.

Crpp.putida binds one cAMP molecule per protein dimer

We have shown previously that $\mathrm{Crp}_{P . \text { putida }}$ is a dimeric protein, which undergoes a strong conformational change upon tight binding of cAMP (Arce-Rodriguez et al., 2012). Regardless of the high quality of these results, some aspects of this interaction remain ambiguous. This previous work showed that an MBP-

23 Crpp. putida fusion protein binds CAMP with an overall stoichiometry of approximately 0.65 , which is close 24 to 0.5 (i.e. 1 molecule of cAMP per dimer of Crp) and occurred in a single binding event, describing a monophasic curve (Arce-Rodriguez et al., 2012). This is an important outcome to take into account, because all the Crp-like proteins described so far bind two or more cyclic nucleotides per protein dimer

27 (Weber and Steitz, 1987; Passner and Steitz, 1997; Stapleton et al., 2010; Cordes et al., 2011; 28 Townsend et al., 2014). One of the hypotheses to explain this odd stoichiometric value is the ultratight 29 affinity of $\mathrm{Crp}_{\text {P. putida }}$ for $\mathrm{CAMP}(K \mathrm{KD}=22.5 \pm 2.8 \mathrm{nM})$. This strong interaction could cause the carryover 30 of cAMP (either produced by E. coli or present in the culture medium) that is still interacting to MBP31 Crpp. putida during protein purification. Therefore, we decided to modify the purification protocol and 
1 pursued to overexpress the MBP-Crpp.putida fusion protein in a E. coli W3110 $\Delta c r p \Delta c y a A$ strain grown

2 in M9-glucose medium in order to obtain a Crpp.putida devoid of any source of cAMP (see Experimental 3 procedures). Also, the ITC reaction buffer was also optimized by increasing concentrations of $\mathrm{KCl}$ to $4250 \mathrm{mM}$ and by adding DTT at $1 \mathrm{mM}$, in order to sustain a reducing milieu for the 6 cysteine residues of 5 the protein. Altogether, these modifications allowed us to conduct the ITC experiments again with a $6>95 \%$ pure, cAMP-less Crp cleaved from MBP (apo-Crpp.putida).

7

8 Fig. 7A shows the titration of apo-Crpp.putida with cAMP. The hyperbolic curve traced from plotting the 9 titration data is virtually identical to the one observed previously for MBP-Crpp.putida (Arce-Rodriguez et 10 al., 2012), the binding being driven by favorable changes in the enthalpy $(\Delta H)$ and entropy $(T \Delta S)$ of the 11 system (Table 2). Likely, the interaction between both molecules yields once again a tight binding for 12 the cyclic nucleotide $\left(K_{D}=45 \pm 3 \mathrm{nM}\right)$. In spite of these similarities, the affinity for the cyclic nucleotide 13 in the apo-protein is somewhat reduced as compared to the fusion protein (Table 2). However, this minor 14 discrepancy is likely to be caused by the increment in the ionic strength to $250 \mathrm{mM} \mathrm{KCl}$ and not by the 15 absence of the MBP tag. Moreover, integration of data with the One Binding Site model results in a very 16 satisfactory fit, which describes only one binding event and confirms without any doubt the stoichiometry 17 of 1 molecule of CAMP per dimer of Crpp.putida. This reflects a scenario in which only one of the (at least) 18 two cAMP binding sites available in the protein becomes occupied.

20 Similarly, the titration of apo-Crpp.putida with cGMP plotted in Fig. 7B was very similar to the interaction 21 of the cyclic nucleotide for the MBP fusion protein (Arce-Rodriguez et al., 2012). Nevertheless, in this 22 case the binding of cGMP is driven by negative entropy changes (Table 2). This unfavorable $\Delta S$ value 23 can have different reasons and is not necessarily caused by an ordering of water molecules at the 24 complex interface. Another important negative contribution to the entropy change is the loss of flexibility 25 of the ligands during the binding process (Jelesarov and Bosshard, 1999). Thus, the cGMP-Crpp. putida 26 complex could occur in a way where the interaction process does not alter the conformational 27 architecture of the binding sites and therefore, the entropy of the system is negative. The affinity of the 28 cGMP for apo-Crpp.putida is $\sim 100$ fold lower than the one observed for cAMP with the same protein. 29 Furthermore, as was the case with CAMP interaction for apo-CrpP.putida, there is just one binding event 30 for cGMP-Crpp.putida complex. Despite the less defined shape of the ITC plot, the One Binding Site model 31 fitting of the data yields again a binding stoichiometry closer to $0.5(0.327 \pm 0.084$, Table 2$)$, which is 
1 consistent with the model proposed that only one molecule of the cyclic nucleotide (cAMP or cGMP) is

2 interacting with the $\mathrm{Crp}_{\text {P.putida }}$ dimeric protein.

4 DISCUSSION

6 We show above that-similarly to $E$. coli and many other bacteria- $P$. putida does have a complete 7 regulatory device that encompasses transcriptional regulator CRP its cognate effector CAMP and the 8 two enzymes that dynamically regulate the levels of this signaling molecule: AMP cyclase CyaA and the 9 phosphodiesterase Pde ${ }^{1}$. the Yet, the actual levels of cAMP borne by $P$. putida, while still retaining their 10 regulatory effects are extremely low. The results shown in this work document that such low levels are 11 the result of the very poor synthesis of CAMP (plausibly due to the equally low down translation of CyaA, 12 its degradation, the efflux to the extracellular milieu and the lack of transport back to the cells. This 13 shortage of CAMP is compensated by the extraordinary affinity of CrpP.putida for the second messenger. 14 In addition, the results document one single event of cAMP binding to a Crp.putida dimer, i.e. a 15 stoichiometry of 0.5 or occupancy of just one monomer of the functional protein dimer. This figure differs 16 notably in respect of what is known for CrpE. coli, where effector/monomer ratios are 1:1 (Weber and 17 Steitz, 1987) if not higher (Gorshkova et al., 1995; Passner and Steitz, 1997; Lin and Lee, 2002). Yet, 18 the ITC data of Fig. 7 shows that only one of the two CAMP binding sites available in the dimer becomes 19 occupied. Binding of one effector molecule to one of the subunits of the dimer thus appears to decrease 20 affinity of the corresponding site in the other subunit in sort of negative cooperativity. A similar behaviour 21 was observed when binding experiments were repeated with cGMP (Fig. 7B). While overall affinity for 22 this effector was lower, the results fitted a stoichiometry close to $0.5(0.327 \pm 0.084$, Table 2$)$, which 23 would indicate binding of a single molecule per dimer i.e. cGMP is also likely to interact with Crpp. putida 24 through the same process as cAMP. Counter-intuitive as it may look, negative cooperativity has been 25 observed in other proteins (Milligan and Koshland, 1993; Teran et al., 2006), including to CrpE. coli, where 26 cAMP binding seems to involve a negative allosteric interaction in the sequential interplay of the effector 27 to its binding sites. Yet, the second CAMP binding event to the non-occupied CrpE. coli monomer is 28 possible because of the high intracellular level of the effector in this bacterium, what restores dimer 29 symmetry (Popovych et al., 2006; Rodgers et al., 2013; Seok et al., 2014; Townsend et al., 2015). In

1 A detailed analysis of each of the Results presented in this article can be found in the Supplementary Materials on line. 
1 contrast, the intriguing possibility that the CAMP-bound Crpp.putida is not symmetric owing to partial

2 occupancy of the dimer opens the possibility that the regulator may recognize non-palindromic DNA

3 sequences-an issue that deserves further studies. This state of affairs is quite different of that found

4 in other bacteria that have the same regulatory players. For instance, $P$. aeruginosa has two 2 ACs

5 (Topal et al., 2012) one of them membrane-bound and clearly controlling cAMP levels for regulation of

6 the Crp homologue Vfr, which in turn rules expression of a suite of virulence genes (Coggan and

7 Wolfgang, 2012). Another remarkable case of unusual Crp/cAMP system is that of Mycobacterium

8 tuberculosis. The device borne by this bacterium included at least $16 \mathrm{AC}$-like proteins (Stapleton et al.,

9 2010; Green et al., 2014) and (in sharp contrast with P. putida) includes a Crp protein with a low affinity

10 for cAMP to compensate the much higher levels of cAMP produced by the many ACs (Green et al.,

11 2014). In between we find the canonical Crp protein of $E$. coli, which possesses a mid-sensitive avidity

12 for cAMP (REF) compared to the P. putida or the M. tuberculosis counterparts.

13

14 The obvious question elicited by the diversity of parameters that rule the interplay Crp-cAMP-cyclase(s)-

15 phosphodiesterase(s) is the biological and evolutionary logic of such a remarkable range of specific

16 values. These make the system to keep the same molecular actors and behave mechanistically the

17 same but delivering quite different transfer functions between the inputs and the outputs of the regulatory

18 device. One revealing detail in this respect is the apparently paradoxical expression of the cyaA gene

19 of P. putida (Fig. 1C and Fig. 4). While transcription initiation of this gene is well detectable, translation

20 seems to be very poor owing to a bad SD motif in its 5'-UTR and a non-optimal codon usage through

21 the coding sequence. Unbalance of translational rates vs. transcription levels typically rule phenotypic

22 variation generated by the noise in protein expression (Trotot et al., 1996). In the case of genes with low

23 transcription but high translational rates, variations in mRNA synthesis result in strong stochastic

24 fluctuations in protein concentration (Supplementary Fig. S4A). Conversely, a gene with high

25 transcription and low translation produces smaller protein bursts that cause only week fluctuations in

26 protein concentration, generating smaller phenotypic variation in the cell population (Supplementary Fig.

27 S4B) (Ozbudak et al., 2002; Kaern et al., 2005). Inefficient translation of cyaAp. putida could thus be a a 28 way to keep a low, non-fluctuating expression of CyaA, a situation that could benefit the environmental 29 lifestyle of $P$. putida. On these bases, we entertain that keeping the same regulatory parts and their 30 relational logic but changing the interaction parameters enables genetic devices to occupy entirely different domains of the functional landscape. 
EXPERIMENTAL PROCEDURES

4 Strains, plasmids, and growth conditions

6 A description of the strains and plasmids employed in this work is summarized in Table 1. All P. putida

7 derivatives were engineered from reference strain KT2440 (Nelson et al., 2002). A mini-Tn5 insertion

8 mutant in the locus PP_4917 (encoding the putative cAMP-phosphodiesterase Pde) was obtained from

9 the P. putida KT2440 mutant library (Duque et al., 2007). The E. coli adenylate cyclase mutant W3110

10 cyaA and the CAMP-hypersensitive strain TP610A were employed for cyaA complementation assays

11 (Milanesio et al., 2011). These experiments were performed in indicator plates prepared by adding 12 maltose at $1.0 \%(\mathrm{w} / \mathrm{v})$ to MacConkey agar base (Miller, 1972). Fermentation of maltose was detected

13 by the appearance of red-colored colonies. E. coli strains CC118, DH5 $\alpha$ and JM109 were used for 14 routine maintenance of plasmids. Additionally, the replication of plasmids with oriR6K suicide replication

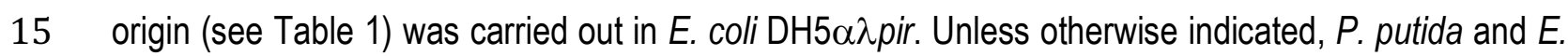
16 coli cells were grown at $30^{\circ} \mathrm{C}$ and $37^{\circ} \mathrm{C}$, respectively, in either rich $L B$ medium or in synthetic mineral 17 M9 medium (Sambrook et al., 1989) supplemented with the C-sources indicated in each case at $0.2 \%$ 18 (w/v). Where necessary, media were amended with the following antibiotics to retain plasmids or to 19 select for plasmid cointegration: ampicillin (Ap), $150 \mu \mathrm{g} / \mathrm{ml}$ for E. coli or $500 \mu \mathrm{g} / \mathrm{ml}$ for P. putida; 20 chloramphenicol $(\mathrm{Cm}), 40 \mu \mathrm{g} / \mathrm{ml}$; kanamycin $(\mathrm{Km}), 50 \mu \mathrm{g} / \mathrm{ml}$; tetracycline $(\mathrm{Tc}), 8 \mu \mathrm{g} / \mathrm{ml}$; streptomycin 21 (Sm), $50 \mu \mathrm{g} / \mathrm{ml}$; and gentamycin (Gm), $10 \mu \mathrm{g} / \mathrm{ml}$.

Recombinant DNA and protein techniques

25 General methods for DNA manipulation were performed following standard protocols described elsewhere (Sambrook et al., 1989). Specific chromosomal segments of $P$. putida were amplified from $27 \sim 100 \mathrm{ng}$ of genomic DNA by means of polymerase chain reactions (PCR) in a buffer containing $1.5 \mathrm{mM}$ $28 \mathrm{MgCl}_{2}, 0.2 \mathrm{mM}$ of each deoxynucleoside triphosphate (dNTP), $0.5 \mu \mathrm{M}$ of oligonucleotides and $1 \mathrm{U}$ of 29 GoTaq DNA polymerase (Promega, Madison, WI, USA). A list of the oligonucleotides used in this work 30 is described in Supplementary Table S1. PCR reactions were run by an initial denaturalization $5 \mathrm{~min}$ at $94^{\circ} \mathrm{C}$ followed by 30 cycles of denaturalization $\left(1 \mathrm{~min}, 94^{\circ} \mathrm{C}\right)$, annealing $\left(1 \mathrm{~min}, 56^{\circ}-62^{\circ} \mathrm{C}\right)$, extension 
$1 \quad\left(1-3 \mathrm{~min}, 72^{\circ} \mathrm{C}\right)$ and one final cycle of extension $\left(10 \mathrm{~min}, 72^{\circ} \mathrm{C}\right)$. Additionally, in PCR reactions carried

2 out with high fidelity Pfu DNA polymerase (Promega, Madison, WI, USA), the extension temperature of reactions was increased to $75^{\circ} \mathrm{C}$. In some cases, the same PCR reaction was directly run on a small amount of bacterial biomass picked from isolated colonies grown on agar plates. Amplified DNA segments were purified from PCR or agarose gels using the NucleoSpin Gel and PCR clean-up kit (Macherey-Nagel, Düren, Germany). Plasmid DNA was extracted from bacterial cells with the commercial Wizard $^{\circledR}$ Plus SV Minipreps DNA Purification kit (Promega, Madison, WI, USA). The restriction endonucleases for DNA digestion and cloning were purchased from New England Biolabs (Ipswich, MA, USA) and used according to the manufacturer indications. Digested DNA was ligated by overnight incubation with T4 DNA ligase (Roche Applied Science, Mannheim, Germany) at $16^{\circ} \mathrm{C}$. When necessary, PCR-amplified DNA fragments were verified by Sanger sequencing (Secugen SL, Madrid,

12 Spain). The mobilization of plasmid DNA into E. coli cells was carried out by chemical transformation of 13 cells prepared in $\mathrm{CaCl} 2$ solution (Sambrook et al., 1989), or by electroporation as described by Wirth et al. (Wirth et al., 1989). In the case of $P$. putida, plasmids were incorporated by conjugative triparental mating using E. coli HB101 (pRK600) as helper strain (de Lorenzo and Timmis, 1994) or by electroporation of cells previously washed and concentrated with $300 \mathrm{mM}$ sucrose as indicated by Choi et al. (Choi et al., 2006).

19 Protein extracts were analyzed by denaturing-polyacrylamide gel electrophoresis (SDS-PAGE) in 10$15 \%$ (w/v) acrylamide/bisacrylamide (29:1) gel cast following standard procedures (Sambrook et al., 1989). Whole cells and proteins were resuspended in a denaturing buffer containing $60 \mathrm{mM}$ Tris- $\mathrm{HCl} \mathrm{pH}$

$226.8,2 \%(\mathrm{w} / \mathrm{v})$ sodium dodecyl sulfate (SDS), $5 \%(\mathrm{v} / \mathrm{v})$ glycerol, $1 \%(\mathrm{v} / \mathrm{v}) \beta$-mercaptoethanol and $0.005 \%$ $23(\mathrm{w} / \mathrm{v})$ bromophenol blue, and boiled during $5 \mathrm{~min}$ prior to loading. At last, proteins were visualized by 24 staining the gels in a solution containing $0.05 \%(\mathrm{w} / \mathrm{v})$ of Coomassie R-250 blue dissolved in $50 \%(\mathrm{v} / \mathrm{v})$ methanol and $10 \%(v / v)$ acetic acid.

Comparison of the aminoacidic sequence of bacterial cAMP-phosphodiesterases.

In order to find a putative cAMP-phosphodiesterase encoded in the chromosome of $P$. putida, the amino

30 acid sequence of $P$. aeruginosa CpdA (Fuchs et al., 2010) was blasted against the non-redundant protein sequences from strain KT2440 using NCBI BLASTP version 2.2.28+ 
1 (http://blast.ncbi.nlm.nih.gov/Blast.cgi) (Altschul et al., 1997). Only a single protein of 266 aa encoded

2 by locus PP_4917 resulted similar to CpdAP. aeruginosa. Following, the aminoacid sequence of E. coli CpdA,

3 Haemophilus influenzae Icc, Mycobacterium tuberculosis Rv0805, Delftia acidovorans PdeA and

4 Pseudomonas aeruginosa CpdA (all of them encoding cAMP-phosphodiesterases) were retrieved from

5 the NCBI database and aligned to the PP_4917 gene product from P. putida using the T-Coffee online

6 server (http://www.tcoffee.org/) (Di Tommaso et al., 2011).

7

8 Construction of $\Delta c r p$ and $\Delta c y a A$ variants of $P$. putida and assembly of vectors to overexpress an

9 optimized version of cyaAp. putida gene

11 The deletion of $\mathrm{crp}$ and cyaA genes in $P$. putida was obtained by the seamless allelic replacement 12 method described in Martínez-García and de Lorenzo (Martinez-Garcia and de Lorenzo, 2011). In the 13 case of crp, the upstream and downstream flanking regions of the gene ( $\sim .5 \mathrm{~kb}$ each) were PCR 14 amplified respectively with primer pairs aacrpU-F/aacrpU-R and aacrpD-F/aacrpD-R. Both amplicons 15 were linked in a single DNA segment by overlap extension (SOE)-PCR using primers aacrpU-F and 16 aacrpD-R. The ensuing $\sim 1 \mathrm{~kb}$ fragment was EcoRI/Sall digested and cloned within the same sites of 17 pEMG, generating plasmid pARCrp9. Meanwhile, the upstream and downstream flanking regions of 18 cyaA ( 0.5 kb each) were also PCR amplified with primer pairs aacyaAU-F/aacyaAU-R and aacyaAD19 F/aacyaAD-R, and joined by (SOE)-PCR in a similar fashion. The $\sim 1 \mathrm{~kb}$ DNA product was EcoRI/BamHI 20 digested and ligated into the same sites of $\mathrm{pEMG}$ to construct plasmid $\mathrm{pJ} \Delta \mathrm{cyaA}$ for further deletion of 21 cyaA. Both suicide vectors were independently mobilized by conjugation to $P$. putida KT2440 already 22 carrying pSW-1 (the latter plasmid encodes the expression of I-Scel endonuclease under the control of $23 \mathrm{Pm}$ promoter). The $\mathrm{Km}$ and $\mathrm{Ap}(500 \mu \mathrm{g} / \mathrm{ml})$ resistant clones were selected and grown overnight in $2 \mathrm{ml}$ 24 of LB medium containing Ap and $15 \mathrm{mM}$ 3-methylbenzoate to drive the expression of I-Scel. Next, 25 induced cells were plated in LB-Agar, and checked for the resolution of the cointegrated plasmid by 26 sensitivity to kanamycin in LB-Agar supplemented with the antibiotic. The Km sensitive clones were 27 selected and tested by PCR to identify the accurate deletion of $c r p$ and cyaA using primer pairs aacrpU28 F/aacrpD-R and aacyaAU-F/aacyaAD-R, respectively. Finally, pSW-1 was diluted by three consecutive 29 subcultures of cells in liquid LB. The loss of this plasmid was confirmed by sensitivity to ampicillin in LB30 Ap plates. Additionally, a special collection of vectors was generated to enhance the synthesis of cAMP 31 in P. putida. For this purpose, the entire cyaA gene of this bacterium was chemically synthesized to 
1 optimize the codon usage, to prevent AT-rich or GC-rich sequence stretches, to eliminate internal cis-

2 acting sites (such as recombination sites or internal RBS sequences) and to avoid RNA secondary

3 structures. Furthermore, a strong Ribosome Binding Site (RBS) was placed upstream of the start codon

4 to enhance the translation of the gene, while two STOP codons were added at the end of the gene

5 (Supplementary Fig. S3). The optimized cyaA version (referred as cyaA-GA from now on) was

6 synthesized by Geneart (Life Technologies, Regensburg, Germany) with flanking KpnI/Sacl sites into

7 the cloning vector pGA15. In order to boost the expression of the optimized CyaA-GA, three expression

8 vectors were generated as follows. First, Kpnl/Sacl restriction enzymes were used to clone cyaA-GA

9 into the same sites of plasmid pVTR-A, thus generating pARC1. This vector transcribes cyaA-GA under

10 the control of IPTG by Ptrc promoter. The resulting lacla/Ptrc $\rightarrow$ cyaA-GA fragment from pARC1 was

11 isolated afterwards as a single Notl segment and cloned into the low copy and broad host range vector

12 pSJ33 to produce plasmid pARC4. Finally, a third cyaA-GA expression vector was generated in

13 pSEVA424 from the SEVA collection (Silva-Rocha et al., 2013). In order to construct this plasmid, the

14 cyaA-GA gene from original pGA15 was excised with Sacl/Spel restriction enzymes and recloned into

15 the same sites of pSEVA424. The resulting broad-host range vector was named pARC5.

17 Fluorescent measurements in cells transformed with the pCAMPS CAMP-reporter system

19 A reporter plasmid was constructed to monitor the in-vivo production of intracellular cAMP as follows:

20 two complementary oligonucleotides (Supplementary Table S1) were designed to generate a double-

21 stranded DNA (dsDNA) fragment encoding the sequence of the Crp-dependent Pcc-41.5 promoter

22 (Gaston et al., 1990). Forward primer aaPCC-5' encodes the leader sequence of $P_{C C-41.5}$, while reverse

23 primer aaPCC-3' contains the complementary strand for aaPCC-5'. The dsDNA was generated in a

24 hybridization mixture containing $250 \mathrm{mM}$ Tris- $\mathrm{HCl} \mathrm{pH} 7.5$ and $20 \mu \mathrm{M}$ of each oligonucleotide. The

25 reaction was started by $5 \mathrm{~min}$ initial denaturation at $95^{\circ} \mathrm{C}$, followed by overnight cooling down. Both

26 complementary oligonucleotides were designed to generate the cohesive ends of the enzymes EcoRI

27 and Sall (at 5' and 3' ends, respectively) when hybridizing. Hence, it was possible to clone the Pcc-41.5

28 into the same restriction sites of the promoterless, GFP-reporter vector pSEVA637 (Table 1) to generate

29 the definitive pCAMPS (which stands for $\underline{\text { cAMP }}$ Sensor). Single colonies of $P$. putida KT2440, $\Delta c y a A$,

$30 \Delta c r p$ and $p d e^{-}$transformed with the reporter pCAMPS were picked from fresh LB plates and inoculated

31 into $1 \mathrm{ml}$ of M9 salts medium supplemented with $\mathrm{Gm}, 0.2 \%(\mathrm{w} / \mathrm{v})$ of the carbon source indicated in each 
1 case (glucose, fructose or succinate) and 1X trace elements solution (Abril et al., 1989). Overnight

2 growing cells were diluted with the same medium to a low optical density $\left(\mathrm{OD}_{600} \mathrm{ca} .0 .005\right)$ and $200 \mu \mathrm{l}$

3 of this preparation was used to inoculate a Microtest ${ }^{\top M}$ 96-well assay plate (BD Falcon). Cultures were

4 incubated at $30^{\circ} \mathrm{C}$ with occasional shaking for 40 hours in the Wallac Victor 2 Microplate Reader (Perkin

5 Elmer, Waltham, MA, USA). At time intervals of $1 \mathrm{~h}, \mathrm{OD}_{600}$ and GFP fluorescence of each culture was

6 measured. The reporter activity was estimated by normalizing the absolute GFP fluorescence to the

$7 \mathrm{OD}_{600}$ values. The output of these experiments is the result of at least three biological replicates. To test

8 the sensitivity of the reporter system to extracellular cAMP, single colonies of wild-type or $\Delta$ cyaA $E$. coli

9 or $P$. putida strains (as indicated) were grown overnight and used to inoculate $200 \mu$ l of M9 salts medium

10 supplemented with $\mathrm{Gm}, 0.2 \%(\mathrm{w} / \mathrm{v})$ of the corresponding carbon source (glucose or maltose) and

11 different concentrations of cAMP (where denoted). Cultures were incubated in the Wallac Victor 2

12 Microplate Reader as described before. GFP fluorescence and $\mathrm{OD}_{600}$ were recorded every 15 minutes.

13 Addition of cAMP was done at mid-exponential phase (as indicated) and the reporter activity was 14 normalized to the $\mathrm{OD}_{600}$ values. Experiments were done in two technical and three biological replicates.

16 Quantification of CAMP by HPLC-MS

18 E. coli and P. putida strains were grown on M9 salts medium containing $0.2 \%(\mathrm{w} / \mathrm{v})$ of the appropriate 19 carbon source until mid-exponential phase $\left(\mathrm{OD}_{600} \mathrm{ca}\right.$. $\left.0.5-0.6\right)$ in 100-ml Erlenmeyer flasks containing $2020 \mathrm{ml}$ of the culture medium. The biomass of a $10-\mathrm{ml}$ culture aliquot was collected by fast centrifugation 21 (14000 rpm, $\left.30 \mathrm{sec}, 0^{\circ} \mathrm{C}\right)$, the supernatant was rapidly removed, and the pellet immediately frozen in 22 liquid $\mathrm{N}_{2}$. cAMP was extracted from cells by vortexing the biomass with $0.5 \mathrm{ml}$ of $10 \mathrm{mM}$ ammonium 23 acetate $(\mathrm{pH}=7.2)$ in $60 \%(\mathrm{v} / \mathrm{v})$ ethanol at $70^{\circ} \mathrm{C}$ for $1 \mathrm{~min}$, followed by an incubation for another min at $2478^{\circ} \mathrm{C}$. The extraction procedure was repeated three times, the supernatants were pooled, and the 25 extract was evaporated to complete dryness in a Speed Vac apparatus at $4^{\circ} \mathrm{C}$. The sediment was kept 26 at $-80^{\circ} \mathrm{C}$ until analysis and, just before quantification, it was resuspended in $100 \mu \mathrm{l}$ of milli-Q water. The 27 supernatants of the $10-\mathrm{ml}$ culture aliquots described above were likewise frozen, lyophilized until 28 complete dryness and resuspended in $0.5 \mathrm{ml}$ of milli-Q water. The cAMP concentration in these samples 29 was determined with a Varian Prostar 210 high-performance liquid chromatography system coupled to 30 a Varian 1200L Triple Quadrupole MS (Varian Medical Systems Inc., Palo Alto, California, USA). The 31 Klawitter method was modified as follows. Samples were run on a Zorbax SB-C18 column (150 mm $\times$ 
$14.6 \mathrm{~mm} \times 5 \mu \mathrm{m}$; Agilent Technologies Corp., Santa Clara, California, USA), using a gradient of two

2 phases. Mobile phase I was methanol and phase II consisted in $95 \%$ (v/v) of an aqueous buffer (10 mM

3 dibutylamine and $15 \mathrm{mM}$ ammonium acetate) and $5 \%(\mathrm{v} / \mathrm{v})$ methanol at a flow rate of $0.5 \mathrm{ml} / \mathrm{min}$. The

4 injection volume was $10 \mu \mathrm{l}$ and the HPLC-ESI-MS analysis was performed in the negative-ion mode.

5 The results of the quantification were obtained in biological duplicates, measured each by three technical

6 replicates.

7

$8 \quad \beta$-galactosidase assays of lacZ transcriptional and translational fusions with cyaAp. putida promoter 9

10 Reporter plasmids were constructed as follows: a lacZ translational fusion of cyaA promoter was 11 generated by PCR amplification of a 492 bp DNA fragment encompassing 400 bp upstream from ATG 12 start codon plus the DNA sequence codifying the 30 first amino acids ( 10 codons) of cyaA. PCR reaction 13 was carried out with oligonucleotides aaPcyaA-F and aaPcyaATrad-R, which includes EcoRI and BamHI 14 restriction sites respectively. The resulting fragment was digested and cloned into the same sites of 15 pSEVA225T to create pARPcyaA1. Also, a lacZ transcriptional fusion of PcyaA promoter was 16 constructed in order to compare the transcription and translation levels of cyaA. The DNA fragment for 17 this construct was obtained by PCR amplification of only the $400 \mathrm{bp}$ upstream the cyaA start codon, 18 using primers aaPcyaA-F (EcoRI) and aaPcyaA-R (BamHI). The resulting $\sim 0.4 \mathrm{~kb}$ fragment was 19 EcoRI/BamHI digested and subsequently cloned in vector pSEVA225 previously cleaved with the same 20 restriction nucleases, generating pARPcyaA2. The two plasmids carrying PcyaA transcriptional and 21 translational fusions were separately transformed in the $P$. putida strains KT2440 wild-type, KT2440 $22 \Delta c r p$ and KT2440 $\Delta c y a A$. The $\beta$-galactosidase activity of the strains described above was measured by 23 means of the ultra-sensitive Galacto-Light Plus ${ }^{\mathrm{TM}}$ commercial system (Applied Biosystems, Foster City, 24 CA, USA). According to the supplier's specifications, this method incorporates a chemiluminiscent 25 substrate for $\beta$-galactosidase enzyme and luminescence enhancers that make the system more 26 sensitive to low amounts of enzyme than traditional methods. Briefly, a single colony was grown in 10 $27 \mathrm{ml}$ of $\mathrm{M} 9$ salts medium supplemented with $\mathrm{Km}$ and $0.2 \%(\mathrm{w} / \mathrm{v})$ of the appropriate carbon source. When 28 cells reached the exponential phase, $500 \mu$ l of the cultures were taken into an Eppendorf tube and spun 29 down by 2 min centrifugation at 14,000 rpm. Cells were resuspended in $200 \mu$ l of lysis buffer [100 mM 30 potassium phosphate $\mathrm{pH} 7.8,0.2 \%(\mathrm{v} / \mathrm{v})$ Triton $\mathrm{X}-100]$, subjected to two freeze-thaw cycles and centrifuged $1 \mathrm{~min}$ at $14.000 \mathrm{rpm}$ to separate cell debris. Then, $20 \mu$ l of lysed supernatant were incubated 
1 with $80 \mu \mathrm{l}$ of reaction buffer (100 mM sodium phosphate $\mathrm{pH} 8.0,1 \mathrm{mM} \mathrm{MgCl}_{2}$ and $1 \mathrm{X}$ Galacto-Plus ${ }^{\circledR}$

2 chemiluminiscent substrate) in the dark for 30 minutes, after which $125 \mu$ l of Sapphire-IITM light emission

3 accelerator were added. The reactions were incubated $1 \mathrm{~min}$ in the dark and the luminescence was

4 recorded in the Wallac Victor 2 Microplate Reader (Perkin Elmer, Waltham, MA, USA). All $\beta$ galactosidase measurements are the result of three biological replicates.

6

$7 \quad$ Purification of P. putida Crp devoid of cAMP

9 E. coli W3110 crp cyaA double mutant was transformed with plasmid pARCrp5, which overexpresses

10 the recombinant MBP-CrpP. putida including a thrombin protease cleavage site placed in the linker of both 11 proteins (Arce-Rodriguez et al., 2012). Transformants were inoculated in $800 \mathrm{ml}$ of M9 salts with $0.2 \%$ $12(\mathrm{w} / \mathrm{v})$ glucose (instead of LB medium) and cultured at $37^{\circ} \mathrm{C}$ to an $\mathrm{OD}_{600}=0.5$. Next, expression of fusion 13 protein was induced with 0.5 mM IPTG during 2 hours. Cells were spun down and resuspended in 50 $14 \mathrm{mM}$ of sodium phosphate buffer $\mathrm{pH} 7.0,200 \mathrm{mM} \mathrm{NaCl}$ and $1 \mathrm{X}$ of a protease inhibitor cocktail (Roche 15 Applied Science, Mannheim, Germany), followed by disruption in a French press (Thermo Electron 16 corporation, Waltham, MA, USA). Soluble extract was separated from cellular debris by centrifugation 17 and then passed through an amylose-resin column (New England Biolabs, Ipswich, MA, USA). After 18 washing extensively the resin with the same resuspension buffer, the recombinant MBP-Crp fusion 19 protein was eluted with the same buffer containing $10 \mathrm{mM}$ maltose. The MBP-Crp eluted fractions were 20 analyzed by SDS-PAGE, and those which produced an apparently homogeneous protein band were 21 pooled and concentrated in a $50 \mathrm{kDa}$ molecular weight-cutoff centrifugal filter device (Millipore, Billerica, 22 MA, USA). Approximately $12 \mathrm{mg}$ of apo-MBP-Crp were recovered and extensively dialyzed against PBS 23 during 8 hours at $4^{\circ} \mathrm{C}$. Prior to cleaving, $0.5 \mathrm{mM}$ DTT was added to the fusion protein, followed by 24 overnight digestion with $240 \mathrm{U}$ of thrombin (Amersham Biosciences) at $22^{\circ} \mathrm{C}$. Immediately after 25 cleavage, the protein mixture was passed through $5 \mathrm{ml}$ of PBS-equilibrated P11 phosphocellulose resin 26 column (Whatman) and washed extensively with $80 \mathrm{ml}$ of PBS. Elution of the MBP-free, apo-CrpP. putida 27 bound to the phosphocellulose resin was carried out with PBS buffer containing $500 \mathrm{mM} \mathrm{KCl}$. The eluted 28 fractions were pooled, concentrated and dialyzed against $50 \mathrm{mM}$ Na phosphate buffer pH 7.0, $250 \mathrm{mM}$ $29 \mathrm{KCl}, 0.67 \mu \mathrm{M}$ DTT and $20 \%(\mathrm{v} / \mathrm{v})$ glycerol. The concentration of the protein was calculated to be 0.8 $30 \mathrm{mg} / \mathrm{ml}$ as determined by absorbance at $280 \mathrm{nM}$, using a calculated extinction coefficient of $11.46 \times 10^{3}$ $31 \mathrm{M}^{-1} \mathrm{~cm}^{-1}$ (ProtParam tool, ExPASy server; (Gasteiger et al., 2005). 
2 Isothermal titration calorimetry (ITC) with purified apo-Crpp. putida

4 Prior to experiments, purified apo-Crp was exhaustively dialyzed in $50 \mathrm{mM} \mathrm{K}$ phosphate buffer $\mathrm{pH}$ 7.0, $5250 \mathrm{mM} \mathrm{KCl}, 1 \mathrm{mM}$ DTT and $20 \%$ (v/v) glycerol. Next, the protein was passed through a $0.22 \mu \mathrm{m}$ pore 6 size filter device and its concentration was accurately determined by UV absorption spectroscopy. 7 Putative effector molecules were prepared by dissolving the pure compound (cAMP, cGMP or AMP) in 8 the same filtered dialysis buffer described above, in order to homogenize ligand and protein solvent. apo-Crpp. putida was diluted to 8-7 $\mu \mathrm{M}$ with the previous buffer and its concentration was accurately

10 calculated by 5 independent measurements of its UV absorption spectroscopy at 280nm. Next, $1.4 \mathrm{ml}$ 11 of protein was titrated in a VP microcalorimeter (MicroCal, Northampton, MA, USA) at $25^{\circ} \mathrm{C}$, conducting 12 a first titration with a single $1.6 \mu \mathrm{l}$ injection of diluted ligands at $200 \mu \mathrm{M}$ and followed by subsequent 13 injections with $4.8 \mu \mathrm{l}$ of the same compounds. The mean enthalpies measured from the injection of 14 ligand into buffer were subtracted from the raw titration data, prior to curve fitting using the One Binding 15 Site model of the MicroCal (Northampton, MA, USA) version of ORIGIN. From the values obtained for $16 K_{A}$ and enthalpy $(\Delta H)$, the dissociation constant $K_{D}$ was determined $\left(K_{D}=1 / K_{A}\right)$ as well as the changes 17 in the free energy $(\Delta G)$ and entropy $(\Delta S)$ using the equation

$$
\Delta G=-R \operatorname{Tn} K_{\mathrm{A}}=\Delta H-T \Delta S
$$
where $R$ is the universal molar gas constant and $T$ the absolute temperature.

ACKNOWLEDGEMENTS

25 To Dr. Mario Mencía for supporting material. To Juhyun Kim for his valuable help in the analysis of RNAseq transcriptomic data. P.I.N. acknowledges financial support by The Novo Nordisk Foundation 27 (NNF10CC1016517 and NNF180C0034818) and the Danish Council for Independent Research 28 (SWEET, DFF-Research Project 8021-00039B). Plan Nacional de I+D+I (grant Bio2010-16937) y Plan 29 Estatal de Investigación Científica y Técnica y de Innovación (BIO2016-76779-P). Rosa Sedano. FCE_1_2017_1_136082 y FCE_1_2019_1_156520. 


\section{Supplementary Materials}

Supplementary Table S1. Oligonucleotides used in this work. Sequences for the corresponding restriction enzymes are underlined.

Supplementary Figure S1. Sequence analysis of $P$. putida PP_4917 gene product compared to other CAMP phosphodiesterases.

Supplementary Figure S2. Overview of the translation initiation region of $P$. putida and $E$. coli cyaA genes.

Supplementary Figure S3. Alignment between the DNA sequence of native cyaA from $P$. putida and its optimized version cyaA-GA.

Supplementary Figure S4. Model of noise generation in protein expression for a transcriptional unit (e.g. GFP) with (A) low rates of transcription vs high translation, of $(B)$ high transcription vs low levels of translation.

\section{Supplementary Discussion}

\section{REFERENCES}

Abril, M.A., Michan, C., Timmis, K.N., and Ramos, J.L. (1989) Regulator and enzyme specificities of the TOL plasmid-encoded upper pathway for degradation of aromatic hydrocarbons and expansion of the substrate range of the pathway. J Bacteriol 171: 6782-6790.

Aiba, H. (1985) Transcription of the Escherichia coli adenylate cyclase gene is negatively regulated by cAMP-cAMP receptor protein. J Biol Chem 260: 3063-3070.

Akkaya, O., Perez-Pantoja, D.R., Calles, B., Nikel, P.I., and de Lorenzo, V. (2018) The Metabolic Redox Regime of Pseudomonas putida Tunes Its Evolvability toward Novel Xenobiotic Substrates. mBio 9.

Altschul, S.F., Madden, T.L., Schaffer, A.A., Zhang, J., Zhang, Z., Miller, W., and Lipman, D.J. (1997) Gapped BLAST and PSI-BLAST: a new generation of protein database search programs. Nucleic acids research 25: 3389-3402.

Arce-Rodriguez, A., Durante-Rodriguez, G., Platero, R., Krell, T., Calles, B., and de Lorenzo, V. (2012) The Crp regulator of Pseudomonas putida: evidence of an unusually high affinity for its physiological effector, cAMP. Environmental microbiology 14: 702-713. 
1 Belda, E., van Heck, R.G., José Lopez-Sanchez, M., Cruveiller, S., Barbe, V., Fraser, C. et al. (2016) The revisited genome of Pseudomonas putida KT2440 enlightens its value as a robust metabolic chassis. Environ Microbiol 18: 3403-3424.

Busby, S., and Ebright, R.H. (1999) Transcription activation by catabolite activator protein (CAP). J Mol Biol 293: 199-213.

Choi, K.H., Kumar, A., and Schweizer, H.P. (2006) A 10-min method for preparation of highly electrocompetent Pseudomonas aeruginosa cells: application for DNA fragment transfer between chromosomes and plasmid transformation. Journal of microbiological methods 64: 391-397.

Coggan, K.A., and Wolfgang, M.C. (2012) Global regulatory pathways and cross-talk control pseudomonas aeruginosa environmental lifestyle and virulence phenotype. Curr Issues Mol Biol 14: $47-70$.

Cordes, T.J., Worzalla, G.A., Ginster, A.M., and Forest, K.T. (2011) Crystal structure of the Pseudomonas aeruginosa virulence factor regulator. J Bacteriol 193: 4069-4074.

Crasnier, M., and Danchin, A. (1990) Characterization of Escherichia coli adenylate cyclase mutants with modified regulation. Journal of general microbiology 136: 1825-1831.

de Lorenzo, V., and Timmis, K.N. (1994) Analysis and construction of stable phenotypes in gramnegative bacteria with Tn5- and Tn10-derived minitransposons. Methods in enzymology 235: 386405.

de Lorenzo, V., Eltis, L., Kessler, B., and Timmis, K.N. (1993) Analysis of Pseudomonas gene products using laclq/Ptrp-lac plasmids and transposons that confer conditional phenotypes. Gene 123: 17 24.

Deutscher, J. (2008) The mechanisms of carbon catabolite repression in bacteria. Curr Opin Microbiol 11: 87-93.

Di Tommaso, P., Moretti, S., Xenarios, I., Orobitg, M., Montanyola, A., Chang, J.M. et al. (2011) TCoffee: a web server for the multiple sequence alignment of protein and RNA sequences using structural information and homology extension. Nucleic acids research 39: W13-17.

Duque, E., Molina-Henares, A.J., Torre, J.d.I., Molina-Henares, M.A., Castillo, T.d., Lam, J., and Ramos, J.L. (2007) Towards a Genome-Wide Mutant Library of Pseudomonas putida Strain KT2440 
1 Pseudomonas. In. Ramos, J.-L., and Filloux, A. (eds): Springer Netherlands, pp. 227-251.

2 Fahrner, K.A., and Berg, H.C. (2015) Mutations That Stimulate flhDC Expression in Escherichia coli K12. J Bacteriol 197: 3087-3096.

4 Fuchs, E.L., Brutinel, E.D., Klem, E.R., Fehr, A.R., Yahr, T.L., and Wolfgang, M.C. (2010) In vitro and in vivo characterization of the Pseudomonas aeruginosa cyclic AMP (cAMP) phosphodiesterase CpdA, required for cAMP homeostasis and virulence factor regulation. J Bacteriol 192: 2779-2790.

7 Gancedo, J.M. (2013) Biological roles of cAMP: variations on a theme in the different kingdoms of life. Biol Rev Camb Philos Soc 88: 645-668.

9 Gasteiger, E., Hoogland, C., Gattiker, A., Duvaud, S.e., Wilkins, M., Appel, R., and Bairoch, A. (2005) Protein Identification and Analysis Tools on the ExPASy Server. In The Proteomics Protocols Handbook. Walker, J. (ed): Humana Press, pp. 571-607.

12

Gaston, K., Bell, A., Kolb, A., Buc, H., and Busby, S. (1990) Stringent spacing requirements for transcription activation by CRP. Cell 62: 733-743.

Gorshkova, I., Moore, J.L., McKenney, K.H., and Schwarz, F.P. (1995) Thermodynamics of cyclic nucleotide binding to the cAMP receptor protein and its T127L mutant. J Biol Chem 270: 2167921683.

Green, J., Stapleton, M.R., Smith, L.J., Artymiuk, P.J., Kahramanoglou, C., Hunt, D.M., and Buxton, R.S. (2014) Cyclic-AMP and bacterial cyclic-AMP receptor proteins revisited: adaptation for different ecological niches. Curr Opin Microbiol 18: 1-7.

Hanahan, D., and Meselson, M. (1983) Plasmid screening at high colony density. Methods Enzymol 100: 333-342.

Herrera, M.C., Daddaoua, A., Fernandez-Escamilla, A., and Ramos, J.L. (2012) Involvement of the global Crp regulator in cyclic AMP-dependent utilization of aromatic amino acids by Pseudomonas putida. J Bacteriol 194: 406-412.

Hufnagel, D.A., Evans, M.L., Greene, S.E., Pinkner, J.S., Hultgren, S.J., and Chapman, M.R. (2016) The Catabolite Repressor Protein-Cyclic AMP Complex Regulates csgD and Biofilm Formation in Uropathogenic Escherichia coli. J Bacteriol 198: 3329-3334. 
1 Jaenecke, S., and Diaz, E. (1999) Construction of plasmid vectors bearing a Notl-expression cassette

Jelesarov, I., and Bosshard, H.R. (1999) Isothermal titration calorimetry and differential scanning calorimetry as complementary tools to investigate the energetics of biomolecular recognition. $\mathrm{J}$ Mol Recognit 12: 3-18.

Joseph, E., Bernsley, C., Guiso, N., and Ullmann, A. (1982) Multiple regulation of the activity of adenylate cyclase in Escherichia coli. Mol Gen Genet 185: 262-268.

Kaern, M., Elston, T.C., Blake, W.J., and Collins, J.J. (2005) Stochasticity in gene expression: from theories to phenotypes. Nat Rev Genet 6: 451-464.

Kessler, B., de Lorenzo, V., and Timmis, K.N. (1992) A general system to integrate lacZ fusions into the chromosomes of gram-negative eubacteria: regulation of the $\mathrm{Pm}$ promoter of the TOL plasmid studied with all controlling elements in monocopy. Mol Gen Genet 233: 293-301.

Lin, S.H., and Lee, J.C. (2002) Communications between the high-affinity cyclic nucleotide binding sites in E. coli cyclic AMP receptor protein: effect of single site mutations. Biochemistry 41: 1185711867.

Ma, J., Campbell, A., and Karlin, S. (2002) Correlations between Shine-Dalgarno sequences and gene features such as predicted expression levels and operon structures. J Bacteriol 184: 5733-5745.

Makman, R.S., and Sutherland, E.W. (1965) Adenosine 3',5'-Phosphate in Escherichia Coli. J Biol Chem 240: $1309-1314$.

Manoil, C., and Beckwith, J. (1985) TnphoA: a transposon probe for protein export signals. Proc Natl Acad Sci U S A 82: 8129-8133.

Martinez-Garcia, E., and de Lorenzo, V. (2011) Engineering multiple genomic deletions in Gramnegative bacteria: analysis of the multi-resistant antibiotic profile of Pseudomonas putida KT2440. Environmental microbiology 13: 2702-2716.

McDonough, K.A., and Rodriguez, A. (2011) The myriad roles of cyclic AMP in microbial pathogens: from signal to sword. Nat Rev Microbiol 10: 27-38. 
1 Milanesio, P., Arce-Rodriguez, A., Munoz, A., Calles, B., and de Lorenzo, V. (2011) Regulatory exaptation of the catabolite repression protein (Crp)-cAMP system in Pseudomonas putida. Environ Microbiol 13: 324-339.

Miller, J.H. (1972) Experiments in molecular genetics. New York: Cold Spring Harbor Laboratory.

Milligan, D.L., and Koshland, D.E., Jr. (1993) Purification and characterization of the periplasmic domain of the aspartate chemoreceptor. J Biol Chem 268: 19991-19997.

Molina-Quiroz, R.C., Silva-Valenzuela, C., Brewster, J., Castro-Nallar, E., Levy, S.B., and Camilli, A. (2018) Cyclic AMP Regulates Bacterial Persistence through Repression of the Oxidative Stress Response and SOS-Dependent DNA Repair in Uropathogenic Escherichia coli. mBio 9.

Moreno, R., Hernandez-Arranz, S., La Rosa, R., Yuste, L., Madhushani, A., Shingler, V., and Rojo, F. (2015) The Crc and Hfq proteins of Pseudomonas putida cooperate in catabolite repression and formation of ribonucleic acid complexes with specific target motifs. Environ Microbiol 17: 105-118.

Mori, K., and Aiba, H. (1985) Evidence for negative control of cya transcription by cAMP and cAMP receptor protein in intact Escherichia coli cells. J Biol Chem 260: 14838-14843.

Nelson, K.E., Weinel, C., Paulsen, I.T., Dodson, R.J., Hilbert, H., Martins dos Santos, V.A. et al. (2002) Complete genome sequence and comparative analysis of the metabolically versatile Pseudomonas putida KT2440. Environmental microbiology 4: 799-808.

Nikel, P.I., and de Lorenzo, V. (2018) Pseudomonas putida as a functional chassis for industrial biocatalysis: From native biochemistry to trans-metabolism. Metab Eng 50: 142-155.

Nikel, P.I., Kim, J., and de Lorenzo, V. (2013) Metabolic and regulatory rearrangements underlying glycerol metabolism in Pseudomonas putida KT2440. Environmental microbiology.

Nikel, P.I., Chavarria, M., Fuhrer, T., Sauer, U., and de Lorenzo, V. (2015) Pseudomonas putida KT2440 Strain Metabolizes Glucose through a Cycle Formed by Enzymes of the Entner-Doudoroff, Embden-Meyerhof-Parnas, and Pentose Phosphate Pathways. J Biol Chem 290: 25920-25932.

Ozbudak, E.M., Thattai, M., Kurtser, I., Grossman, A.D., and van Oudenaarden, A. (2002) Regulation of noise in the expression of a single gene. Nat Genet 31: 69-73.

Passner, J.M., and Steitz, T.A. (1997) The structure of a CAP-DNA complex having two cAMP molecules bound to each monomer. Proc Natl Acad Sci U S A 94: 2843-2847. 
1 Perez-Martin, J., and de Lorenzo, V. (1996) VTR expression cassettes for engineering conditional phenotypes in Pseudomonas: activity of the Pu promoter of the TOL plasmid under limiting concentrations of the XyIR activator protein. Gene 172: 81-86.

Phillips, A.T., and Mulfinger, L.M. (1981) Cyclic adenosine 3',5'-monophosphate levels in Pseudomonas putida and Pseudomonas aeruginosa during induction and carbon catabolite repression of histidase synthesis. J Bacteriol 145: 1286-1292.

Popovych, N., Sun, S., Ebright, R.H., and Kalodimos, C.G. (2006) Dynamically driven protein allostery. Nat Struct Mol Biol 13: 831-838.

Rodgers, T.L., Townsend, P.D., Burnell, D., Jones, M.L., Richards, S.A., McLeish, T.C. et al. (2013) Modulation of global low-frequency motions underlies allosteric regulation: demonstration in CRP/FNR family transcription factors. PLoS Biol 11: e1001651.

Rojo, F. (2010) Carbon catabolite repression in Pseudomonas : optimizing metabolic versatility and interactions with the environment. FEMS Microbiol Rev 34: 658-684.

Sambrook, J., Fritsch, E.F., and Maniatis, T. (1989) Molecular cloning: A laboratory manual. New York: Cold Spring Harbor Laboratory.

Seok, S.H., Im, H., Won, H.S., Seo, M.D., Lee, Y.S., Yoon, H.J. et al. (2014) Structures of inactive CRP species reveal the atomic details of the allosteric transition that discriminates cyclic nucleotide second messengers. Acta Crystallogr D Biol Crystallogr 70: 1726-1742.

Shimada, T., Fujita, N., Yamamoto, K., and Ishihama, A. (2011) Novel roles of cAMP receptor protein (CRP) in regulation of transport and metabolism of carbon sources. PLoS One 6: e20081.

Silva-Rocha, R., Martinez-Garcia, E., Calles, B., Chavarria, M., Arce-Rodriguez, A., de Las Heras, A. et al. (2013) The Standard European Vector Architecture (SEVA): a coherent platform for the analysis and deployment of complex prokaryotic phenotypes. Nucleic acids research 41: D666675.

Stapleton, M., Haq, I., Hunt, D.M., Arnvig, K.B., Artymiuk, P.J., Buxton, R.S., and Green, J. (2010) Mycobacterium tuberculosis cAMP receptor protein (Rv3676) differs from the Escherichia coli paradigm in its CAMP binding and DNA binding properties and transcription activation properties. J Biol Chem 285: 7016-7027. 
1 Teran, W., Krell, T., Ramos, J.L., and Gallegos, M.T. (2006) Effector-repressor interactions, binding of a single effector molecule to the operator-bound TtgR homodimer mediates derepression. J Biol Chem 281: 7102-7109.

Topal, H., Fulcher, N.B., Bitterman, J., Salazar, E., Buck, J., Levin, L.R. et al. (2012) Crystal structure and regulation mechanisms of the $\mathrm{CyaB}$ adenylyl cyclase from the human pathogen Pseudomonas aeruginosa. J Mol Biol 416: 271-286.

Townsend, P.D., Jungwirth, B., Pojer, F., Bussmann, M., Money, V.A., Cole, S.T. et al. (2014) The crystal structures of apo and cAMP-bound GIxR from Corynebacterium glutamicum reveal structural and dynamic changes upon cAMP binding in CRP/FNR family transcription factors. PLoS One 9: e113265.

Townsend, P.D., Rodgers, T.L., Glover, L.C., Korhonen, H.J., Richards, S.A., Colwell, L.J. et al. (2015) The Role of Protein-Ligand Contacts in Allosteric Regulation of the Escherichia coli Catabolite Activator Protein. J Biol Chem 290: 22225-22235.

Trotot, P., Sismeiro, O., Vivares, C., Glaser, P., Bresson-Roy, A., and Danchin, A. (1996) Comparative analysis of the cya locus in enterobacteria and related gram-negative facultative anaerobes. Biochimie 78: 277-287.

Ullmann, A., and Monod, J. (1968) Cyclic AMP as an antagonist of catabolite repression in Escherichia coli. FEBS Lett 2: 57-60.

Weber, I.T., and Steitz, T.A. (1987) Structure of a complex of catabolite gene activator protein and cyclic AMP refined at 2.5 A resolution. J Mol Biol 198: 311-326.

Wirth, R., Friesenegger, A., and Fiedler, S. (1989) Transformation of various species of gram-negative bacteria belonging to 11 different genera by electroporation. Molecular \& general genetics : MGG 216: $175-177$.

Wong, S.M., and Mekalanos, J.J. (2000) Genetic footprinting with mariner-based transposition in Pseudomonas aeruginosa. Proceedings of the National Academy of Sciences of the United States of America 97: 10191-10196.

Xiao, Y., Liu, H., He, M., Nie, L., Nie, H., Chen, W., and Huang, Q. (2020) A crosstalk between c-diGMP and CAMP in regulating transcription of GcsA, a diguanylate cyclase involved in swimming motility in Pseudomonas putida. Environ Microbiol 22: 142-157. 
1 Xue, J., Tan, B., Yang, S., Luo, M., Xia, H., Zhang, X. et al. (2016) Influence of cAMP receptor protein 2 (CRP) on bacterial virulence and transcriptional regulation of allS by CRP in Klebsiella 3 pneumoniae. Gene 593: 28-33.

4 Yang, D., Wang, Z., Ma, J., Fu, Q., Wu, L., Wang, H. et al. (2020) Glycine Cleavage System and cAMP 5 Receptor Protein Co-Regulate CRISPR/cas3 Expression to Resist Bacteriophage. Viruses 12.

6 Yanisch-Perron, C., Vieira, J., and Messing, J. (1985) Improved M13 phage cloning vectors and host 7 strains: nucleotide sequences of the M13mp18 and pUC19 vectors. Gene 33: 103-119.

8 Yuste, L., Hervas, A.B., Canosa, I., Tobes, R., Jimenez, J.I., Nogales, J. et al. (2006) Growth phase9 dependent expression of the Pseudomonas putida KT2440 transcriptional machinery analysed 10 with a genome-wide DNA microarray. Environ Microbiol 8: 165-177. 
1 Table 1. Strains and plasmids used in this work.

2

\begin{tabular}{|c|c|c|}
\hline Strain/plasmid & Description / relevant characteristics & Reference \\
\hline \multicolumn{3}{|l|}{ E. coli strains } \\
\hline CC118 & $\begin{array}{l}\mathrm{F}^{-}, \Delta(\text { ara-leu }) 7697, \operatorname{araD} 139, \Delta(\text { lac) } \mathrm{X} 74, \text { phoA } \Delta 20, \text { galE, } \\
\text { galK, thi, rpsE, rpoB, } \arg \mathrm{E}(\mathrm{Am}), \operatorname{rec} \mathrm{A} 1\end{array}$ & $\begin{array}{l}\text { (Manoil and } \\
\text { Beckwith, 1985) }\end{array}$ \\
\hline $\mathrm{DH} 5 \alpha$ & $\begin{array}{l}\mathrm{F}^{-}, \text {supE44, slacU169, ( } \phi 80 \text { lacZDM15), hsdR17, (rk- } \\
\left.\mathrm{mk}^{+}\right) \text {, recA1, endA1, thi1, gyrA, relA }\end{array}$ & $\begin{array}{l}\text { (Hanahan and } \\
\text { Meselson, 1983) }\end{array}$ \\
\hline JM109 & $\begin{array}{l}\mathrm{F}^{\prime}, \text { traD36, } \operatorname{proA}^{+} \mathrm{B}^{+} \text {, lacla, } \Delta(\text { lacZ)M15 } \Delta \text { (lac-proAB), } \\
\text { glnV44 e14-, gyrA96, recA1, relA1, endA1, thi, hsdR17 }\end{array}$ & $\begin{array}{l}\text { (Yanisch-Perron } \\
\text { et al., 1985) }\end{array}$ \\
\hline $\mathrm{DH} 5 \alpha \lambda$ pir & $\lambda$ pir phage lysogen of $\mathrm{DH} 5 \alpha$ & Lab collection \\
\hline HB101 & $\mathrm{Sm}^{\mathrm{R}}$, hsdR-M+, pro, leu, thi, recA & $\begin{array}{l}\text { (Sambrook et al., } \\
\text { 1989) }\end{array}$ \\
\hline W3110 cyaA & $\begin{array}{l}\text { Prototrophic, } \mathrm{F}^{-}, \mathrm{I}^{-} \text {, IN (rrnD-rrnE)1, rph-1; cyaA deletion } \\
\text { derivative of } \mathrm{W} 3110 \text { strain }\end{array}$ & $\begin{array}{l}\text { (Milanesio et al., } \\
\text { 2011) }\end{array}$ \\
\hline W3110 crp cyaA & $\begin{array}{l}\text { Prototrophic, } \mathrm{F}^{-}, \mathrm{I}^{-}, \mathrm{IN}(r r n \mathrm{D}-\mathrm{rrn} \mathrm{E}) 1, \mathrm{rph}-1 \text {; crp and cyaA } \\
\text { double mutant }\end{array}$ & $\begin{array}{l}\text { (Milanesio et al., } \\
\text { 2011) }\end{array}$ \\
\hline TP610A & $\begin{array}{l}\mathrm{F}^{-} \text {, thi-1, thr-1, leuB6, pro, lacY1, tonA2I, supE44, } \lambda \text {-hsdR } \\
\text { hsdM recBC lop-11 lig cya-610; spontaneous mutant of } \\
\text { strain TP610 with hypersensitivity to low levels of cAMP }\end{array}$ & $\begin{array}{l}\text { (Crasnier and } \\
\text { Danchin, 1990) }\end{array}$ \\
\hline \multicolumn{3}{|c|}{ P. putida strains } \\
\hline KT2440 & $\begin{array}{l}r s d \mathrm{R} \text {; prototrophic, wild-type strain derived of } P \text {. putida mt- } \\
2 \text { without pWWO plasmid }\end{array}$ & $\begin{array}{l}\text { (Nelson et al., } \\
\text { 2002) }\end{array}$ \\
\hline KT2440 $\Delta c r p$ & KT2440 derivative with a full deletion of crp & This work \\
\hline KT2440 $\Delta$ cyaA & KT2440 derivative with a full deletion of cyaA & This work \\
\hline KT2440 pde $e^{-}$ & $\begin{array}{l}\mathrm{Km}^{\mathrm{R}} \text {, RifR; KT2440 derivative carrying a chromosomal } \\
\text { insertion of a miniTn5-Km in locus PP_4917 (pde) }\end{array}$ & $\begin{array}{l}\text { (Duque et al., } \\
\text { 2007) }\end{array}$ \\
\hline
\end{tabular}




\begin{tabular}{|c|c|c|}
\hline \multicolumn{3}{|l|}{ Plasmids } \\
\hline pRK600 & $\begin{array}{l}\mathrm{Cm}^{\mathrm{R}} \text {, oriV ColE1, tra }{ }^{+} \mathrm{mob}^{+} \text {of } \mathrm{RK} 2 \text {; helper plasmid for } \\
\text { mobilization in tripartite conjugations }\end{array}$ & $\begin{array}{l}\text { (Kessler et al., } \\
\text { 1992) }\end{array}$ \\
\hline pEMG & $\begin{array}{l}\mathrm{Km}^{\mathrm{R}} \text {, oriV } \mathrm{R} 6 \mathrm{~K} \text {, lacZ } \alpha \text { with two flanking I-Scel sites } \\
\mathrm{Cm}^{\mathrm{R}}, \mathrm{Km}^{\mathrm{R}}, \mathrm{Ap}{ }^{\mathrm{R}}, \mathrm{Sm}, \mathrm{Gm}, \mathrm{Tc}\end{array}$ & $\begin{array}{l}\text { (Martinez-Garcia } \\
\text { and de Lorenzo, } \\
\text { 2011) }\end{array}$ \\
\hline pARCrp9 & $\begin{array}{l}\mathrm{Km}^{\mathrm{R}} \text {, suicide pEMG carrying the upstream and } \\
\text { downstream flanking regions of } P \text {. putida crp gene }\end{array}$ & This work \\
\hline $\mathrm{pJ} \Delta$ cyaA & $\begin{array}{l}\mathrm{Km}^{\mathrm{R}} \text {, suicide pEMG carrying the upstream and } \\
\text { downstream flanking regions of } P \text {. putida cyaA gene }\end{array}$ & This work \\
\hline pSW-1 & $\begin{array}{l}A p^{R} \text {, oriV RK2, xylS, bearing a } P m \rightarrow I-\text {-scel transcriptional } \\
\text { fusion }\end{array}$ & $\begin{array}{l}\text { (Wong and } \\
\text { Mekalanos, 2000) }\end{array}$ \\
\hline pGA15cyaA-GA & $\begin{array}{l}\mathrm{Km}^{\mathrm{R}} \text {, oriV ColE1, lacZ } \alpha, \text { pGA15 cloned with the optimized } \\
\text { version of } P \text {. putida cyaA (cyaA-GA) }\end{array}$ & This work \\
\hline pVTR-A & $\begin{array}{l}\mathrm{Cm}^{\mathrm{R}} \text {, oriV PSC101, Laclq/IPTG inducible expression } \\
\text { cassette inserted as a Notl segment }\end{array}$ & $\begin{array}{l}\text { (Perez-Martin and } \\
\text { de Lorenzo, 1996) }\end{array}$ \\
\hline pARC1 & $\begin{array}{l}\text { CmR }{ }^{R} \text {, pVTR-A cloned in frame with cyaA-GA gene from } \\
\text { pGA15cyaA-GA }\end{array}$ & This work \\
\hline pSJ33 & $\mathrm{Km}^{\mathrm{R}}$, oriV RSF1010, $\mathrm{P}_{l a c}$, lacZ $\alpha$ & $\begin{array}{l}\text { (Jaenecke and } \\
\text { Diaz, 1999) }\end{array}$ \\
\hline pARC4 & $\begin{array}{l}\mathrm{Km}^{\mathrm{R}} \text {, pSJ33 bearing the Notl fragment from pARC1 which } \\
\text { includes the expression cassette for cyaA-GA }\end{array}$ & This work \\
\hline pSEVA424 & $\mathrm{Sm} / \mathrm{Sp}^{\mathrm{R}}$, oriV RK2, oriT, laclq/P $\mathrm{P}_{\text {trc }}$ expression cassette & $\begin{array}{l}\text { (Silva-Rocha et } \\
\text { al., 2013) }\end{array}$ \\
\hline pARC5 & $\begin{array}{l}\mathrm{Sm} / \mathrm{Sp}{ }^{\mathrm{R}} \text {, pSEVA424 bearing the expression of cyaA-GA } \\
\text { optimized gene }\end{array}$ & This work \\
\hline pSEVA637 & $\begin{array}{l}\mathrm{Gm}^{\mathrm{R}} \text {, oriV pBBR1, oriT, promoter-less cloning vector } \\
\text { including the gfp as a reporter gene }\end{array}$ & $\begin{array}{l}\text { (Silva-Rocha et } \\
\text { al., 2013) }\end{array}$ \\
\hline
\end{tabular}




\begin{tabular}{|c|c|c|}
\hline pCAMPS & $\begin{array}{l}\mathrm{Gm}^{\mathrm{R}} \text {, pSEVA637 cloned with the sequence of } \mathrm{P}_{\mathrm{CC}-41.5} \\
\text { artificial promoter }\end{array}$ & This work \\
\hline pARCrp5 & $\begin{array}{l}A p^{R} \text {, pMAL-C2T overexpression vector harboring the } \\
\text { MBP-Crp fusion protein }\end{array}$ & $\begin{array}{l}\text { (Arce-Rodriguez } \\
\text { et al., 2012) }\end{array}$ \\
\hline pARC2 & $\begin{array}{l}\mathrm{Cm}^{\mathrm{R}} \text {, pVTR-A with its Notl insert altogether replaced by a } \\
\text { segment bearing the cyaA gene of } E \text {. coli expressed } \\
\text { through its native transcription and translation signals. }\end{array}$ & $\begin{array}{l}\text { (Milanesio et al., } \\
\text { 2011) }\end{array}$ \\
\hline pVLT31 & $\begin{array}{l}\mathrm{Tc}^{\mathrm{R}} \text {, oriV RSF1010, broad-host range Laclq/IPTG } \\
\text { inducible expression vector }\end{array}$ & $\begin{array}{l}\text { (de Lorenzo et al., } \\
\text { 1993) }\end{array}$ \\
\hline pMZC5 & $\begin{array}{l}\mathrm{Tc}^{\mathrm{R}} \text {, pVLT31 inserted with the } P \text {. putida native cyaA gene } \\
\text { sequence }\end{array}$ & $\begin{array}{l}\text { (Milanesio et al., } \\
\text { 2011) }\end{array}$ \\
\hline pSEVA225T & $\begin{array}{l}\mathrm{Km}^{\mathrm{R}} \text {, oriV } \mathrm{RK} 2 \text {, oriT, promoter-less cloning vector for } \\
\text { translational fusions with lacZ }\end{array}$ & $\begin{array}{l}\text { (Silva-Rocha et } \\
\text { al., 2013) }\end{array}$ \\
\hline pARPcyaA1 & $\begin{array}{l}\mathrm{Km}^{\mathrm{R}} \text {, pSEVA225T harboring a } \mathrm{P}_{\text {cyaA }} \rightarrow \text { cyaA'-'lacZ } \\
\text { translational fusion }\end{array}$ & This work \\
\hline pSEVA225 & $\begin{array}{l}\mathrm{Km}^{\mathrm{R}} \text {, oriV } \mathrm{RK} 2 \text {, oriT, promoter-less cloning vector for } \\
\text { transcriptional fusions with lacZ }\end{array}$ & $\begin{array}{l}\text { (Silva-Rocha et } \\
\text { al., 2013) }\end{array}$ \\
\hline pARPcyaA2 & $\begin{array}{l}\mathrm{Km}^{\mathrm{R}} \text {, pSEVA225 harboring a translational fusion of } \mathrm{P}_{\text {cyaA }} \\
\text { with lacZ }\end{array}$ & This work \\
\hline
\end{tabular}


1 Table 2. Thermodynamic parameters obtained from titration of apo-Crpp. putida with putative effectors.

2

\begin{tabular}{|c|c|c|c|c|c|c|}
\hline Ligand & Stoichiometry & $K_{A}\left(M^{-1}\right)$ & $K_{\mathrm{D}}$ & $\begin{array}{c}\Delta H \\
\text { (kcal/mol) }\end{array}$ & $\begin{array}{c}T \Delta S \\
(\mathrm{kcal} / \mathrm{mol})\end{array}$ & $\underset{\text { (kcal } / \mathrm{mol})}{\Delta G}$ \\
\hline \multicolumn{7}{|c|}{ MBP-Crpp. putida ${ }^{a}$} \\
\hline cAMP & $0.65 \pm 0.01$ & $(4.4 \pm 0.5) \times 10^{7}$ & $22.5 \pm 2.8 \mathrm{nM}$ & $-5.97 \pm 0.03$ & $4.47 \pm 0.1$ & $-10.44 \pm 0.1$ \\
\hline cGMP & $0.49 \pm 0.02$ & $(3.9 \pm 0.4) \times 10^{5}$ & $2.6 \pm 0.3 \mu \mathrm{M}$ & $-4.16 \pm 0.27$ & $3.46 \pm 0.3$ & $-7.62 \pm 0.06$ \\
\hline AMP & $n d^{b}$ & & & & & \\
\hline \multicolumn{7}{|c|}{ apo-Crp ${ }_{P . \text { putida }}$} \\
\hline CAMP & $0.498 \pm 0.002$ & $(2.2 \pm 0.2) \times 10^{7}$ & $45.0 \pm 3.4 \mathrm{nM}$ & $-4.89 \pm 0.03$ & $5.11 \pm 0.05$ & $-10.0 \pm 0.1$ \\
\hline cGMP & $0.327 \pm 0.084$ & $(1.7 \pm 0.2) \times 10^{5}$ & $5.7 \pm 0.7 \mu \mathrm{M}$ & $-15.24 \pm 4.3$ & $-8.09 \pm 4.3$ & $-7.15 \pm 0.07$ \\
\hline
\end{tabular}

3

4 a. Data obtained from (Arce-Rodriguez et al., 2012)

5 b. No binding was observed for non-cyclic AMP

6

7

8 
2

3

4 5
6

7

8 Expression patterns of genes pde (called formerly cpdA) encoding 3',5'-cyclic-nucleotide
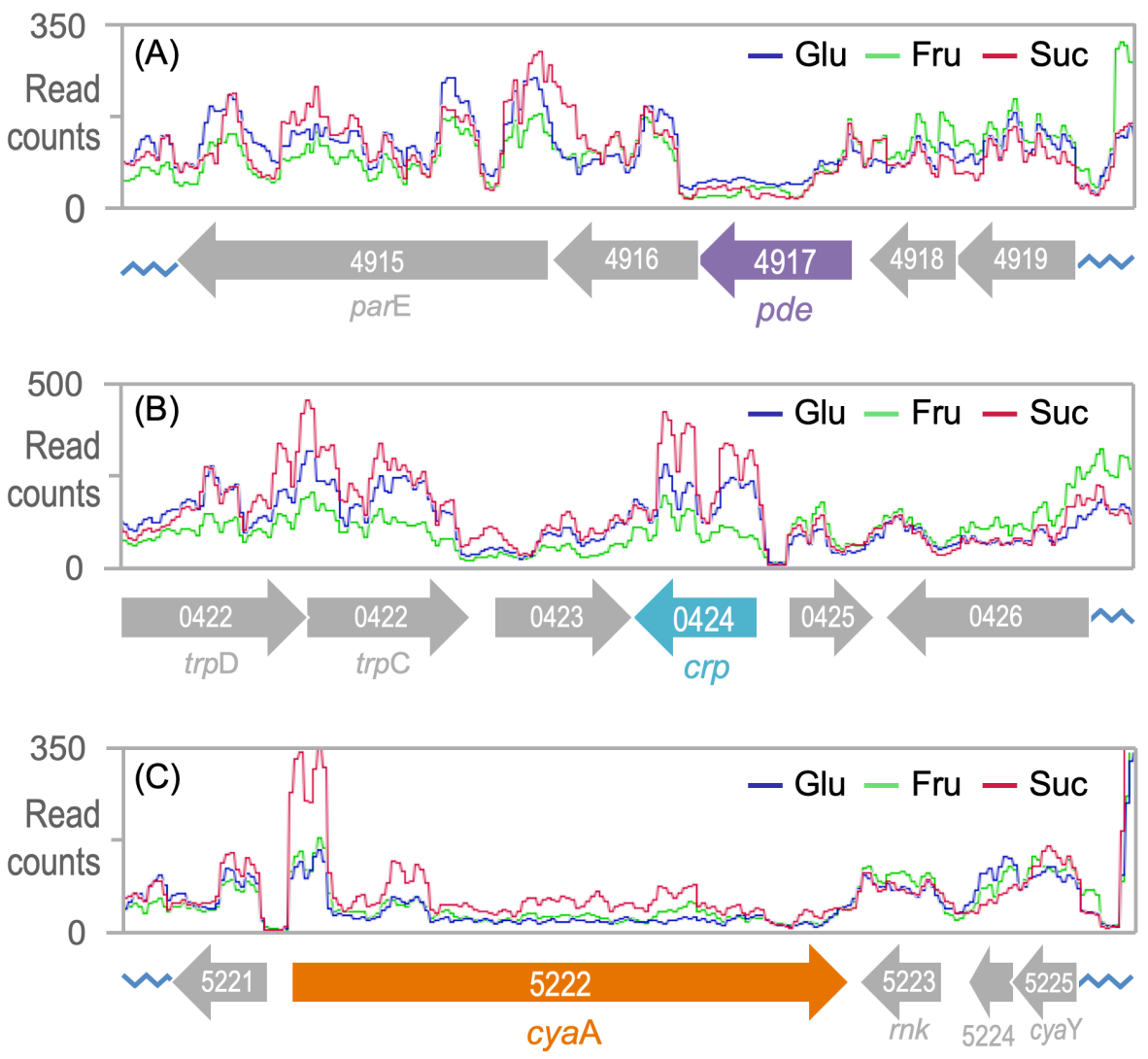

Fig. 1. Genomic context and expression profiles of the 3 constituents of the pde/crp/cyaA regulatory device.

\section{FIGURES}

phosphodiesterase (A), crp for the cAMP regulatory protein (B) and cyaA, adenylate cyclase (C) in

10 Pseudomonas putida KT2440 analysed by RNA-seq deep sequencing transcriptomics are shown

11 aligned with their respective genomic locations and the code for their PP numbers. Panels show the

12 sequence coverage plots for samples taken during mid-log phase from cultures grown on M9 salts with

13 succinate, glucose or fructose as the sole $\mathrm{C}$ source as indicated in the conditions described in (Nikel et

14 al., 2013)]. The representative region shown below the plot charts represent the genome context

15 surrounding each gene. Note that expression of the three genes does not change significantly respective

16 to the carbon source. Also, note the low expression of all genes, specially pde and cyaA. 
1 Fig. 2. Role of crp, cyaA and pde genes on the activity of the (cAMP-Crp)-dependent Pcc(-41.5) promoter 2 in exponential and stationary phase of growth.
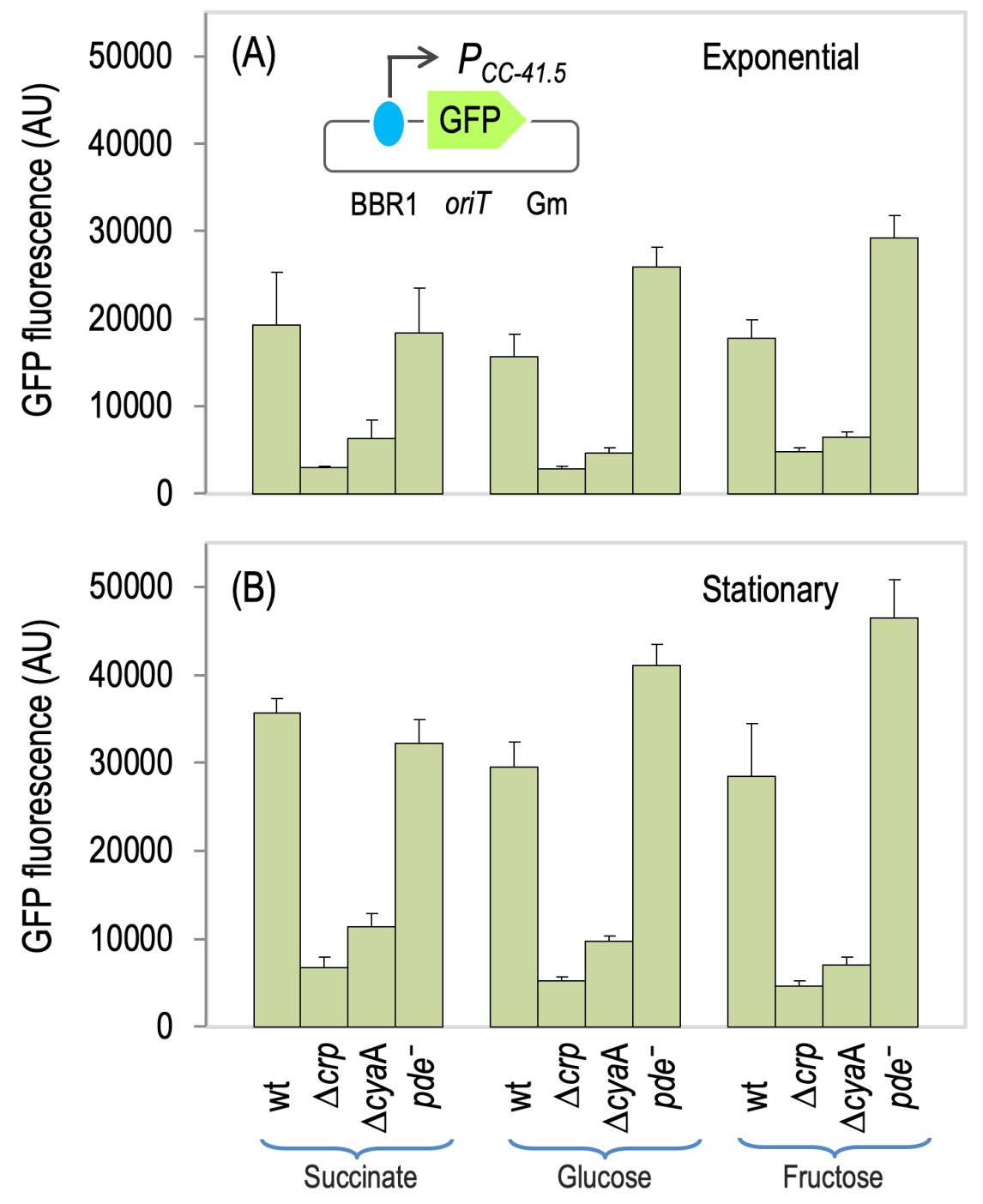

6 The functional parts of the reporter plasmid pCAMPS (sketched an insert in the upper panel) include an

$7 \quad$ BBR1 origin of replication, a transcriptional fusion between the synthetic Crp-responsive promoter PcC-

8 41.5), a marker gene for gentamicin resistance $(\mathrm{Gm})$ and an origin of transfer (oriT). pCAMPS was

9 transformed in wild type P. putida KT2440 and its derived $\Delta c r p, \Delta c y a A$ and $p d e^{-}$mutants. These strains

10 were inoculated in M9 salts supplemented with succinate, glucose or fructose as the only carbon source

11 and grown at $30^{\circ} \mathrm{C}$ in microtiter plates. The $\mathrm{OD}_{600}$ and the GFP specific fluorescence were flowed each

12 hour in a Victor 2 multireader and values at mid-exponential phase (A) or stationary phase (B) measured 13 as shown. The basal fluorescence endowed by the promoterless vector (pSEVA637) was subtracted in 14 all cases. The experiment was carried out at least in triplicate. 
1 Fig. 3. Quantification of the cAMP production in (A) E. coli and (B-C) $P$. putida cells grown in different 2 carbon sources.

3
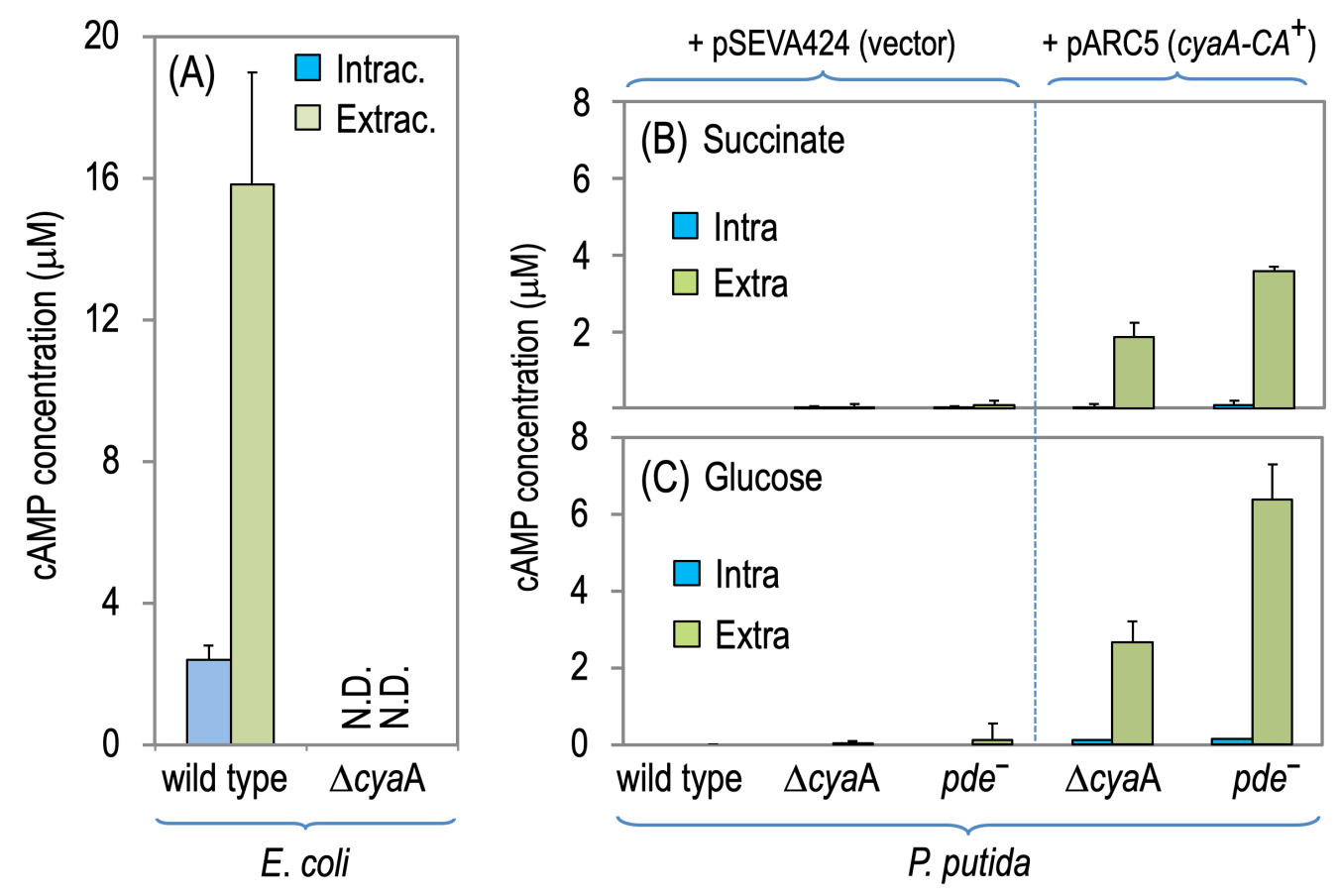

4

5

6 Note that $E$. coli W3110 was cultured in succinate as carbon source, while its $\Delta c y a A$ mutant was grown

7 in glucose (see text for details). The levels of CAMP were determined in both cells and supernatants of

8 wild-type E. coli and P. putida strains, along with some mutants of the cAMP-Crp system, as explained

9 in Experimental Procedures. The maximum cAMP levels in $P$. putida were induced by the expression of 10 the optimized CyaA-GA protein borne in plasmid pARC5.

11

12 
1 Figure 4. The cyaA gene of $P$. putida is transcribed efficiently, but it is poorly translated into its 2 corresponding protein.

3

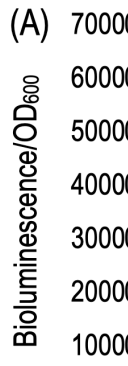

4

5

6

7

8

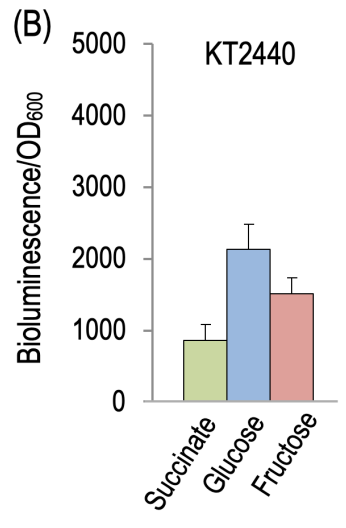

(A) $\beta$-galactosidase activity of translational (green) and transcriptional (blue) fusions of $\mathrm{P}_{\text {cyaA }}$ promoter 7 with lacZ gene. Plasmids encoding the promoter fusions were transferred to the indicated $P$. putida hosts 8 and the enzymatic activity was measured by the Galacto-Light Plus ${ }^{\mathrm{TM}}$ method in cultures grown on succinate, glucose or fructose as the only carbon source. The basal level of promoter-less plasmids 10 (pSEVA225T and pSEVA225) was respectively subtracted from measured LacZ activity. The 1 experiment was run on triplicates. (B) Zoom-in of the $\beta$-galactosidase activity in P. putida KT2440 2 bearing the translational fusion of $\mathrm{P}_{\text {cyaA }}$ (PARPcyaA1) grown in 3 different carbon sources, as depicted 3 in (A). Note the change in the scale of the $y$-axis. 
1 Fig. 5. Qualitative comparison of the cAMP content in E. coli cyaA-deficient cells harboring the native 2 cyaA of $P$. putida and its optimized counterpart (cyaA-GA).

3
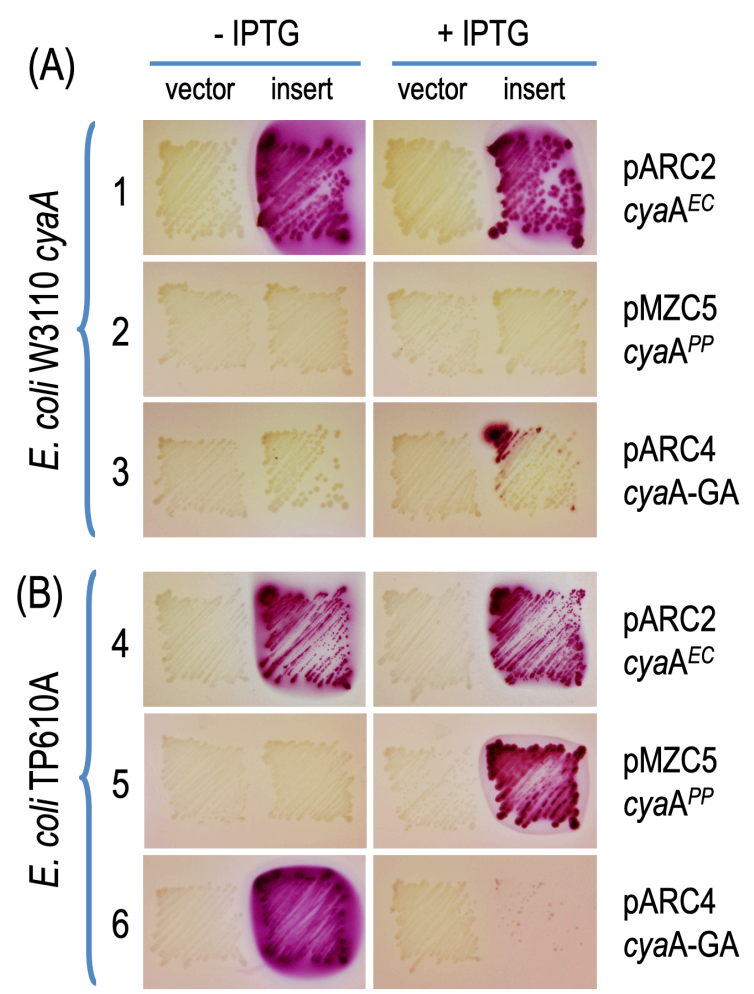

4

5

6 E. coli $\triangle$ cyaA and the cAMP-hypersensitive TP610A strain were transformed with two plasmids bearing

7 the indigenous cyaAp. putida gene or its optimized version (cyaA-GA) in which the codon usage, the

8 translation initiation region and other features were modified to improve its translation (see Experimental

9 procedures for details). The cAMP production was correlated with the rescue of Mal+ phenotype (red-

10 colored colonies) in MacConkey Agar plates. Note the toxicity of overexpressing the cyaA-GA in the

11 hypersensitive TP610A E. coli strain, which inhibits growth of the corresponding cells.

12 
1 Fig. 6. Effect of the addition of extracellular cAMP to cyaA defective strains of $E$. coli and P. putida.

2

(A)

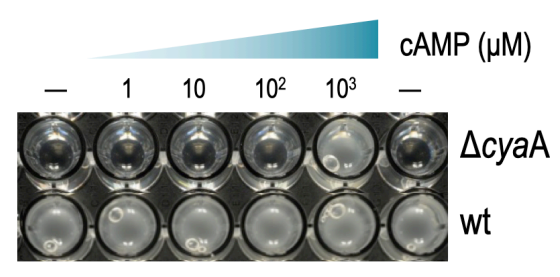

(B)
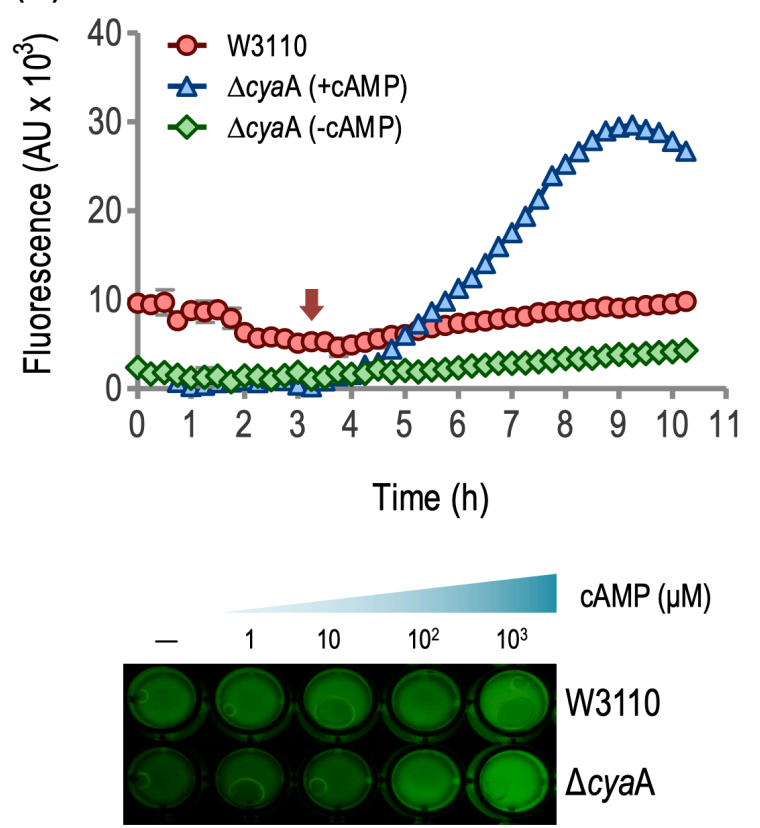

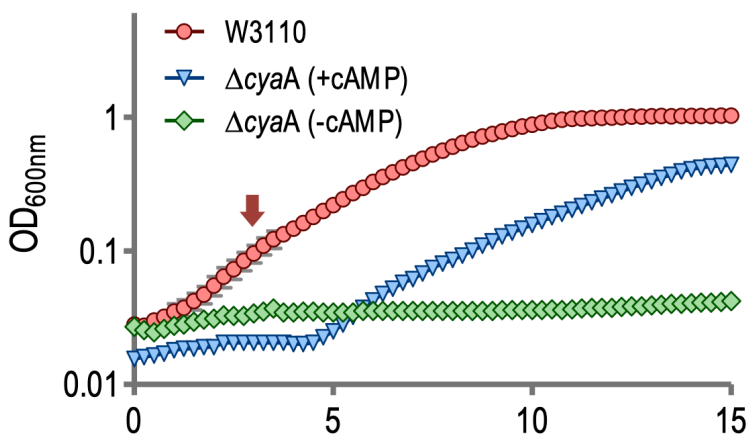

Time (h)

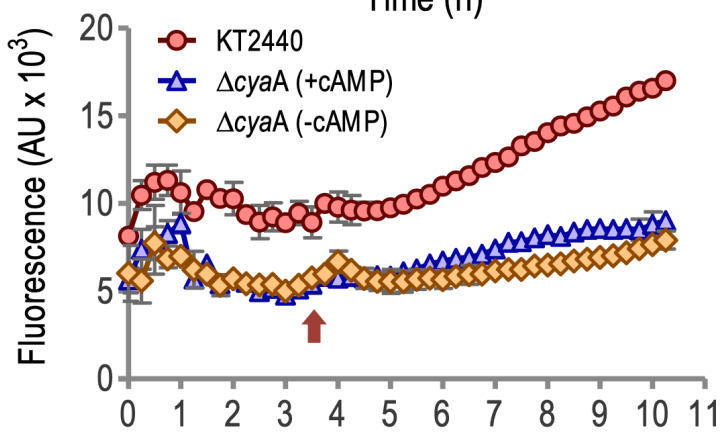

Time (h)

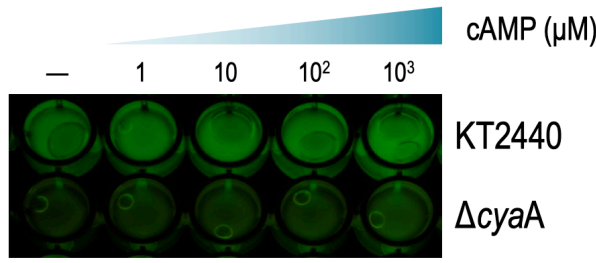


2

3 Fig. 7. Isothermal titration microcalorimetry of apo-Crpp. putida interacting with (A) cAMP and (B) cGMP. 4

(A)

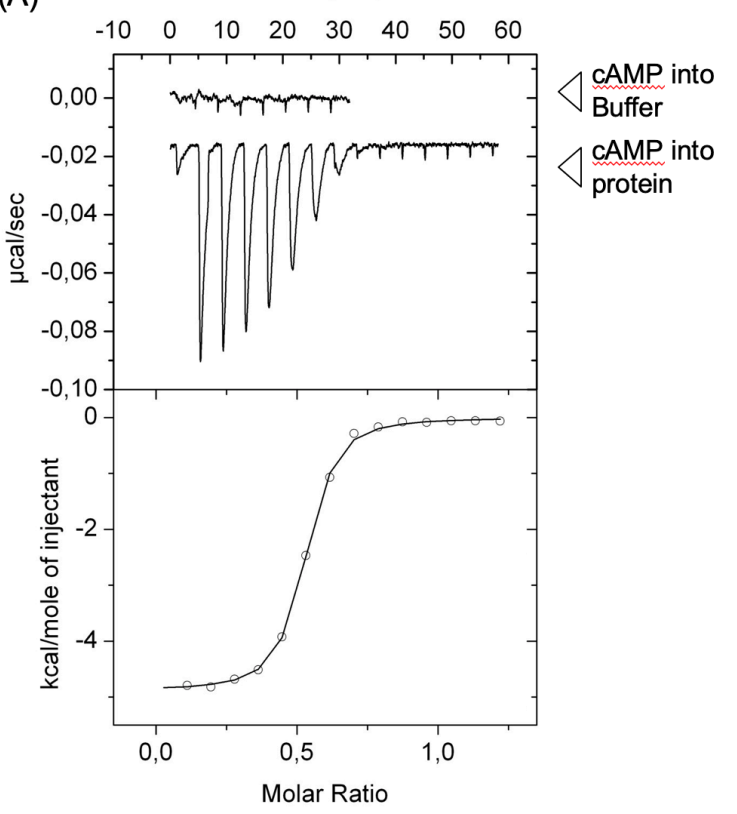

(B) Time $(\mathrm{min})$

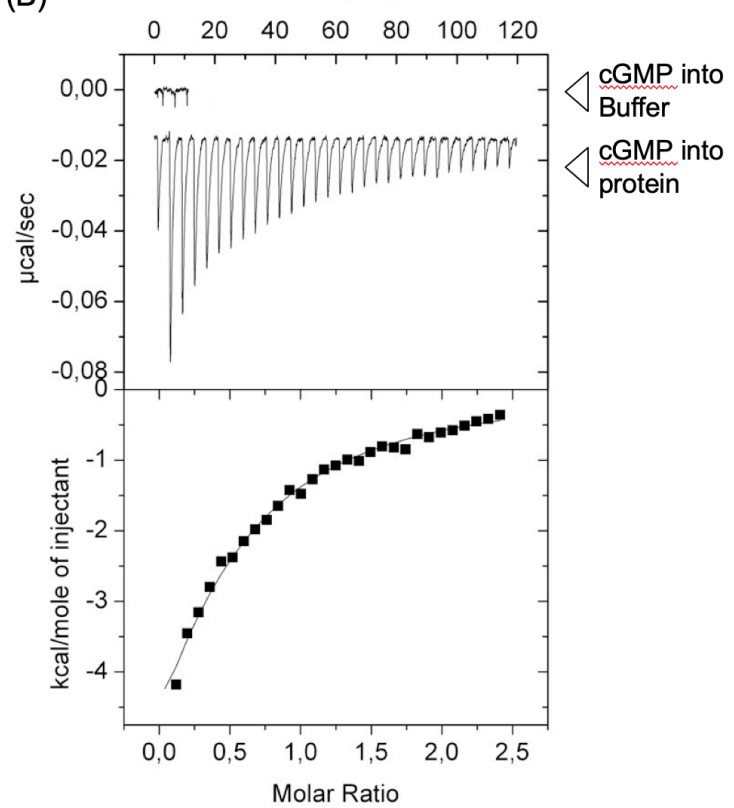

7 The upper panels plot the raw data obtained from titrations with the cyclic nucleotides. The first titration

8 in these panels exhibits the injection of the effector molecule into buffer without protein. The lower panels

9 represent the integrated and dilution-corrected curves fitted from raw data with the One Binding Site

10 model of the MicroCal version of ORIGIN software. Thermodynamic parameters obtained from curves 11 are summarized in Table 2. 